CUADERNOS DE ESTUDIOS GALLEGOS, LXI Núm. 127 (enero-diciembre 2014), págs. 177-217

ISSN: $0210-847 \mathrm{X}$

DOI: $10.3989 /$ ceg.2014.127.06

\title{
EL RETABLO MAYOR DE LA IGLESIA DE SANTA BAIA DE VEDRA EN LOS SIGLOS XVIII Y XIX*
}

\author{
Francisco JaVier Novo SÁNCHEZ \\ Universidade de Santiago de Compostela
}

\footnotetext{
La presente investigación tiene su origen en la memoria histórica del proyecto de restauración del retablo mayor de la iglesia de Santa Baia de Vedra, llevada a cabo por la firma ALFA ARTE RESTAURACIÓN en 2013 y 2014.
} 


\section{EL RETABLO MAYOR DE LA IGLESIA DE SANTA BAIA DE VEDRA EN LOS SIGLOS XVIII Y XIX}

\section{RESUMEN}

La presente investigación tiene por objeto el estudio del retablo mayor de la iglesia parroquial de Santa Baia de Vedra, perteneciente a la archidiócesis de Santiago de Compostela, una de los mejores obras de madera policromada del Barroco gallego, ejecutada por Manuel de Leis hacia 1758. La estructura y el aparato ornamental acusan la influencia de los dos grandes maestros de la Galicia del siglo XVIII, Fernando de Casas y Novoa y Simón Rodríguez, y de los tratados de arquitectura. Una parte de la imaginería se esculpe para este retablo y otra proviene de etapas anteriores. La primera policromía, encomendada a Andrés Cardama, no se administra hasta un siglo después, en 1865.

Palabras Clave: Vedra, retablo, Manuel de Leis, Barroco, siglo XVIII, policromía.

\section{O RETABLO MAIOR DA IGREXA DE SANTA BAIA DE VEDRA NOS SÉCULOS XVIII E XIX}

\section{RESUMO}

O obxectivo da presente investigación é o estudo do retablo maior da igrexa parroquial de Santa Baia de Vedra, integrada na arquidiocese de Santiago de Compostela, unha das mellores obras de madeira policromada do Barroco galego, executada por Manuel de Leis preto de 1758. A estrutura e a decoración acusan a influencia dos dous grandes mestres da Galicia do século XVIII, Fernando de Casas y Novoa e Simón Rodríguez, e dos tratados de arquitectura. Algunhas imaxes escúlpense para este retablo e outras pertencen a etapas anteriores. A primeira policromía, encomendada a Andrés Cardama, non se administra ata un século máis tarde, en 1865.

Palabras Clave: Vedra, retablo, Manuel de Leis, Barroco, século XVIII, policromía.

\section{THE MAIN ALTARPIECE OF THE CHURCH OF SANTA BAIA DE VEDRA IN THE $18^{\text {th }}$ AND $19^{\text {th }}$ CENTURIES}

\section{AbSTRACT}

This research deals with the study of the main altarpiece of thechurch of Santa Baia de Vedra, in the Archdiocese of Santiago de Compostela, one of the best examples of Galician Baroque polychrome wood sculpture, carved by Manuel de Leis around 1758. The structure and ornamentation are influenced by Galicia's two principal eighteenth century architects, Fernando Casas y Novoa and Simón Rodríguez, and also by architectural treatises. Some of the images were carved at this time and others date from earlier. The first polychromy were not apply until a century later, in 1865, being its author Andrés Cardama.

KEY WORDS: Vedra, altarpiece, Manuel de Leis, Baroque, $18^{\text {th }}$ century, polychromy. 
Recibido/Received: 10/03/2014

Aceptado/Accepted: 03/09/2014

$\mathrm{E}$

1 beneficio de Santa Baia de Vedra cuenta desde 1738 con un nuevo pastor: Pedro Tomás Figueroa y Sarmiento. La mentalidad emprendedora y munificente de este párroco ${ }^{1}$ hará posible, junto al generoso impulso de las cofradías ${ }^{2}$, la remoción integral en clave barroca de la capilla mayor de la iglesia parroquial. No se apreciarían aún signos de ruina preocupantes en la fábrica cuando hacia 1744 encarga a Francisco de Moas por 3.500 reales un nuevo retablo mayor y los actuales colaterales, dedicados a Cristo en el instante de la Flagelación y a la Virgen de la Soledad, cantidad que incluye una cuantiosa aportación del rector ${ }^{3}$. El retablo del presbiterio era de corto alcance a juzgar

\footnotetext{
1 Se incorpora a su puesto el 14 de noviembre de dicho año y como muestra de liberalidad entrega a la iglesia "la ymagen de Santa Eulalia su patrona, que está sobre la puerta principal pintarla a toda costa a óleo, y ponerla su laureola. Diez y ocho purificadores seis de ellos de batista, y los doze de cambrai ordinario. El Niño Jesús, que está en el altar maior pintarle, y vestirle. Un paño para cubrir el cálix de diferentes colores muy bueno. La imagen nueva de Nuestra Señora del Rosario hazerla, y pintarla a su costa, darle encaxes finos para las bueltas, y collar, y un rosario de piedra pórfido para tener en las manos, todo ello de valor, y estimación de [se obvia la cantidad]. Un escaparate para tener dentro de él la imagen de Nuestra Señora en la sacristía. Unos manteles finos para el altar maior de seis baras menos quarta de largo con sus encajes finos de coste cada bara de veynte reales de vellón. Más otros treinta y dos purificadores de mortes, o paño blanco, y lienzo. Más una mesa de corporales finos con sus encajes". Archivo Histórico Diocesano de Santiago (AHDS), Fondo parroquial, Santa Baia de Vedra, Fábrica (1702-1842), fol. 89v.

2 Las hermandades de Vedra se hallan bajo la advocación del Santísimo Sacramento, Nuestra Señora del Rosario y San Ciprián y San Roque, esta última con capilla propia en los aledaños de la parroquial.

3 El primer pago, abonado por la Fábrica parroquial durante el transcurso de su construcción, asciende a 1.080 reales, y lo recibe el maestro "a quenta de los retablos que está haciendo para la yglesia" (AHDS, Fondo parroquial, Santa Baia de Vedra, Fábrica (1702-1842), fol. 100v). Las tres entregas siguientes, cuyo total suma 2.420 reales, se satisfacen tras la finalización de los trabajos y son responsabilidad de la cofradía del Rosario, que colabora con dos remesas de 900 y 520 reales, y del presbítero, que aporta 1.000 reales "por su deuozión" (AHDS, Fondo parroquial, Santa Baia de Vedra, Cofradía de Nuestra Señora del Rosario (1744-1872), fols. 2r y 3r). A tales desembolsos hay que añadir, en 1746, 80 reales liquidados al cantero Ignacio Porto por el trabajo de "arrancar las piedras que sirven de pedestal al retablo mayor, componerlas con las molduras que tienen y hazer el plano del altar"; otros 16 reales que percibieron los carreteros que trajeron el retablo desde San-
} 
por las exiguas dimensiones del recinto ${ }^{4}$ y el limitado número de imágenes que albergaba ${ }^{5}$. En torno a 1748, coincidiendo con la contratación de los trabajos de policromía a Andrés Barreiro ${ }^{6}$, labor por la que se embolsa 1.000 reales y que afecta al menos a los retablos laterales ${ }^{7}$, comienza a manifestarse la quiebra de la capilla, por lo que el cura acude en busca de ayuda al cabildo de la catedral de Santiago por su condición de patrono de la misma ${ }^{8}$. En 1755 la reforma resulta ya ineludible por el peligro de derrumbe, y para afrontarla, y la de la sacristía anexa, hace llamar a Ángel Antonio Mouriño, que quince años atrás había em-

tiago; y 18 reales más que cobraron los carpinteros Andrés Álvarez y Alonso de Barros por ayudar a asentarlo (AHDS, Fondo parroquial, Santa Baia de Vedra, Fábrica (1702-1842), fols. 105v-106r).

${ }^{4}$ Véase la cita correspondiente a la nota n. $^{\circ} 11$.

5 En un apunte de las cuentas referentes al retablo se aclara que en la cantidad pactada de 3.500 reales no van incluidos "los dos santos y ángeles de el altar maior" (AHDS, Fondo parroquial, Santa Baia de Vedra, Cofradía de Nuestra Señora del Rosario (1744-1872), fol. 3r. Cfr. María Dolores Villaverde Solar, Patrimonio artístico del arciprestazgo de Ribadulla, vol. III, A Coruña, Edinosa, 2000, pág. 361). Por sistema se hará alusión a esta publicación siempre y cuando las citas extraídas de los archivos eclesiásticos compostelanos coincidan exactamente con las que figuran en ella, teniendo en cuenta que se han realizado para el presente trabajo nuevas transcripciones que, en buena medida, difieren de las publicadas en dicho libro o las completa, o ambas cosas.

6 Este maestro figura, aunque con tres entradas distintas, en el diccionario de José Couselo BouZAS, Galicia artística en el siglo XVIII y primer tercio del XIX, Santiago de Compostela, Instituto Teológico Compostelano, 2005 (1ª ed.: 1933), págs. 199-200.

7 En las cuentas de Fábrica de 1748 figura un apunte de 532 reales que tiene como destinatario a "Andrés Barreiro, maestro pintor, vezino de la ciudad de Santiago, a quenta de lo que deuía hauer por la pintura de los dos colaterales de la yglesia" (AHDS, Fondo parroquial, Santa Baia de Vedra, Fábrica (1702-1842), fols. 117v). En la contabilidad de la cofradía del Santísimo de ese mismo año se registra la salida de otros 468 reales, dados a "Andrés Barreiro maestro pintor, vezino de la ciudad de Santiago para quenta de la pintura de los colaterales de la yglesia" (AHDS, Fondo parroquial, Santa Baia de Vedra, Cofradía del Santísimo Sacramento (1742-1880), fol. 23r.). En la visita de 1748, el obispo Cayetano Gil Taboada manda que se "acabe de dorar el retablo mayor y los dos colaterales" (AHDS, Fondo general, Visita pastoral, leg. 12, 1748-1750, fol. 65v), pero todo indica que la encomienda a Barreiro no incluía el retablo mayor, pues la documentación parroquial no refiere nada al respecto, a diferencia de los otros dos, como se demuestra en las citas precedentes. Esta teoría se confirma con el encargo de policromía realizado para este retablo en el siglo XIX, que no es un repinte, como cabría suponer, sino su primera capa de color y oro, hipótesis que constatan los análisis que se han elaborado en el marco de los trabajos de restauración

8 En el capítulo del 31 de mayo de 1748 se acuerda, como respuesta a la petición de amparo remitida por el párroco, visitar dicha capilla "con uno de los aparejadores", y en atención al contenido del informe se ordena que "se fixen cédulas para los reparos que necesita" (Archivo de la Catedral de Santiago (ACS), Libro 54 de Actas capitulares (1745-1750), IG 523, fols. 200v y 219v. Cfr. M. ${ }^{\mathrm{a}}$ D. Villaverde Solar, Patrimonio..., vol. III, pág. 357). En el supuesto de que se ejecutasen, los trabajos debieron limitarse a meras reparaciones de urgencia, pues hasta el 23 de marzo de 1751 no hay una preocupación real y un compromiso firme por parte de los prebendados, que de nuevo a instancias del párroco deciden "que sobre la tasa de dichos reparos se le ajuste a dicho cura hasta mil y quinientos reales, siendo de su quenta el todo de dichos reparos, con que no ha de pedir otra cosa aunque ensanche la capilla y haga alguna más obra" (ACS, Libro $55^{\circ}$ de Actas capitulares (1750-1756), IG 524, fol. 19r-v. Cfr. M. ${ }^{a}$ D. Villaverde Solar, Patrimonio..., vol. III, pág. 357). 
prendido la renovación de la iglesia de San Miguel de Valga ${ }^{9}$. El relato que hace el sacerdote de Vedra sobre el estado de conservación y la estrechez de la estancia no puede ser más gráfico:

Aviéndose arruinado la bóbeda de la capilla maior de esta yglesia de Santa Eulalia de Vedra, caiéndosele los pedazos de rampantes, o arcos antiguos, que sostenían unas losas que hacían la tal bóbeda, y procurado repararla con mucho dispendio lo mejor que se pudo, para que vinieron maestros de Santiago, entendidos en la facultad, y viendo, y experimentando, que todo era perdido, pues volvieron a caer otros dos o tres pedazos de dichos rampantes, o arcos, y que la piedra de que estaban hechos, era tosca, y sin consistencia alguna por su mala calidad, he determinado, con el favor de Dios, y debajo de la protección de María Santísima de los Dolores hacer de nuevo dicha capilla maior, y siendo antes mui reducida, pues tenía solas tres sepulturas útiles, adelantarla y ensancharla en la manera que hoi se halla, y que tiene veinte y dos inclusas dos de los lados de la epístola, y evangelio. A este fin llamé a Ángel Mourín, maestro de obras, vezino de San Miguel de Valga, quien aviendo trahido diferentes oficiales, que principiaron a arrancar, y quebrantar la piedra el día viernes, catorze de marzo de el año de mil sietezientos y cinquenta y cinco, y echada a tierra la capilla maior y sacristía el día quinze de junio, y principiado a abrirse los cimientos 139 r el día siguiente diez, y seis, se puso la primera piedra de la obra el día viernes veinte, y siete del referido mes de junio, después de aver precedido una misa solemne a María Santísima, a que asistieron muchos señores eclesiásticos, entre ellos algunos señores canónigos de Santiago, que se hallaban al tiempo de recreación en mi casa, y otras muchas personas distinguidas, que concurrieron para este fin. Fue prosiguiendo la obra, que habiendo finalizado la capilla maior, que se hizo toda de cantería con su bóbeda de arista, y un tragaluz mui grande, y mui ancho, que la llena de luz, determiné proseguir haciendo la sacristía, la que se hizo también de cantería con unas paredes mui gruesas, y fuertes, capazes de resistir la bóbeda de cielo raso, que se llama entre los facultativos arco a la regla, la que tiene dos tragaluzes mui anchos y capazes, y dos alazenas grandes y hermosas ${ }^{10}$.

\footnotetext{
9 J. Couselo Bouzas, Galicia artística..., pág. 471.

${ }^{10}$ AHDS, Fondo parroquial, Santa Baia de Vedra, Cofradía del Santísimo Sacramento (1742-1880), fols. $38 \mathrm{v}-39$ r. Esta cita documental y las tres siguientes han sido perfeccionadas tomando como
} 
Ultimada la parte arquitectónica en 1758, Figueroa ajusta con Manuel de Leis la construcción del actual retablo, adaptado a la nueva cabecera y "arreglado a una planta" que le será proporcionada por el clérigo promotor (fig. 1). Patrono y artista pudieron tomar como referencia el diseño empleado sólo diez años antes por Moas para el retablo mayor malogrado, que el nuevo maestro acomodaría a su gusto. Este aprovechamiento cobra fuerza, como se verá, cuando se verifican las afinidades entre el retablo que hoy ocupa el testero y los que amueblan el cuerpo de la iglesia, que Moas había fabricado junto a la obra reemplazada. Así narra el titular de la parroquia todo lo relacionado con los primeros momentos de su ejecución:

Concluida toda esta obra en el mes de noviembre de el año de mil sietezientos, y cinquenta, y ocho, y atendiendo a que haviendo quedado tan bien hecha, era preciso hazerle un retablo correspondiente, he contratado con don Manuel de Leys, maestro escultor, vezino de la ciudad de Santiago para que me lo hiciera, arreglado a una planta, que le he dado, quien aviendo visto la capilla maior, tomado sus medidas, y héchose cargo de todo, tomó de su quenta hacerlo, y dármelo puesto, y asentado dentro de un año, debaxo de las condiciones, y importe, que por ello avía de darle, y hemos contratado. En esta inteligencia principió a hazer la obra, e yo quedé con el deseo de que al año siguiente en el día que acostumbra hacerse en esta yglesia la función del Santísimo Sacramento, que es la dominica infraoctava del Corpus, que en aquel año quadraba en el día veinte y quatro de mayo, pudiese ver a Su Magestad sacramentado en un nuevo y hermoso tabernáculo. A ese fin he tomado el ramo de la cofradía, constituiéndome mayordomo para tal año y tiempo prescrito ${ }^{11}$.

Pero la desventura se ha querido cebar con Leis y las arcas de la feligresía, pues un incendio desatado en el taller del escultor obliga a rehacer un retablo ya concluido, no pudiendo ser asentada la nueva estructura hasta 1761. De ello se queja el abad amargamente, achacando la adversidad a la providencia divina, que había permitido

base la transcripción editada en su día en el artículo de José Manuel GARcía IGLESIAS, "Los retablos barrocos de la iglesia parroquial de Santa Baia de Vedra", en Jubilatio. Homenaje de la Facultad de Geografía e Historia a los profesores Don Manuel Lucas Álvarez y Don Ángel Rodríguez, González, II, Santiago de Compostela, Universidade, 1987, págs. 633-634.

11 AHDS, Fondo parroquial, Santa Baia de Vedra, Cofradía del Santísimo Sacramento (1742-1880), fol. 39r. 


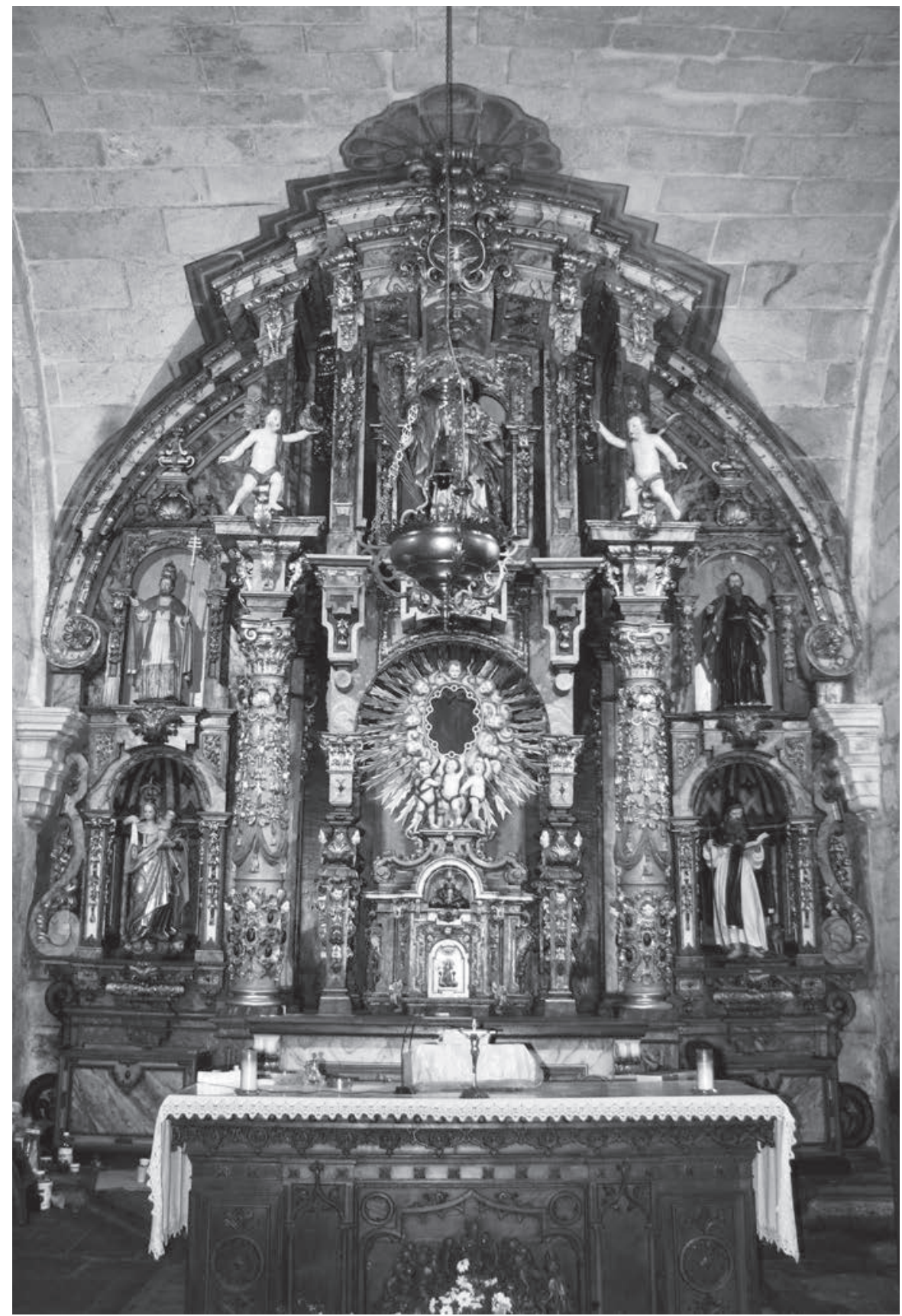

Figura 1.- Santa Baia de Vedra. Retablo mayor. Manuel de Leis. c. 1758. 
que no pudiese lograr este gusto para tal tiempo $139 \mathrm{v}$ por haver sucedido la desgracia de havérsele ardido la casa del referido don Manuel de Leys el día diez y seis de septiembre de dicho año de sesenta a la una de la noche, y en ella la maior parte del retablo, que estaba hecho, por lo que fue preciso bolver a hacerlo de nuevo con muchos más costes, y dispendios, que me ha tenido. Últimamente, haviéndose hecho con la maior hermosura y disposición, según se ve, y puesto en su lugar en el mes de agosto, y principio de septiembre de el año de mil sietezientos, y sesenta, y uno, en el día veinte de septiembre hize la bendición del retablo y se colocó Su Magestad en el sagrario, quedando expuesto todo el día ${ }^{12}$.

Finalizados los trabajos y superada la desdicha, el regocijo popular y del clero congregado, la liturgia de la misa, las procesiones, la música, los cantos, la danza, los fuegos y luminarias y, en definitiva, la teatralidad y la fiesta sustituyeron al cincel, la gubia y el infortunio. Precede a los actos de celebración

una misa solemne en el altar de Nuestra Señora de los Dolores, fuegos al mediodía y a la noche con muchos fuegos y luminarias. Para hacer esta función en un todo alegre, y plausible vinieron de la Santa Yglesia Cathedral de Santiago quatro violines, un violón, y trompa de caza, sochantre, y tiple, o capón, que lo fue don Santiago Vitorica. Ha havido dos danzas de un gusto exquisito, y primoroso, y de diferentes disfrazes con sus gixantes. Cantó la música una misa de las de Roma con bello ayre y melodía en el día domingo después de haver cantado el te Deum laudamus, quando la colocación del Señor en el sagrario, y los himnos correspondientes en la procesión, que se hizo con Su Magestad sacramentado alrededor de la yglesia. En este día dijo la misa el doctor don Joseph Benito Novio, rector de San Andrés de Trobe, a quien asistieron de diácono, y subdiácono don Antonio Escudero, rector de Santa María de Teo, y don Joseph González de la Riva, rector de la de Santa María de Vaamonde. En este día predicó el sermón don Juan Nieto y Quintana, rector de San Andrés de Yllobre. Por la tarde del domingo se cantaron las vísperas mui solemnes por la música, a que asistieron todos los señores curas, y aclesiásticos de la redonda, que lo havían hecho a la mañana en número de más de treinta, las que /40r se finalizaron con un villancico de un gusto

\footnotetext{
12 Ibíd., fol. 39r-v.
} 
mui exquisito. Por la noche de dicho día domingo ha havido mucha abundancia de fuegos artificiales de diferentes géneros, los que coronó un castillo de fuego mui hermoso, y bastante grande, y alto, que se hizo delante de la puerta principal de la yglesia. Al día siguiente lunes veinte, y uno de septiembre, se zelebró la función de el Sacramento, cantando la música una misa, asimismo de Roma de una composición especial, y mui diferente de la del día antecedente. La zelebró don Antonio Escudero, rector de Santa María de Teo, y asistieron de asistentes don Domingo Rodríguez de Arijón, rector de San Pedro de Villanueva, y don Joseph González de la Riva, rector de la de Santa María de Vaamonde. El sermón de este día lo he predicado yo. Por la tarde ha havido la procesión con la maior magnificencia, que se ha podido componer en una aldea, a que asistieron los señores curas y eclesiásticos expresados, juntamente con todas las personas distinguidas de este contorno, y muchas de la ciudad de Santiago, y otras partes que han concurrido a ver las fiestas por la noticia, que se ha esparcido. Ha havido quatro villancicos en la procesión en otros tantos altares, que se han puesto en el distrito de ella, que llegó a los cruzeros, dando buelta de allí a la yglesia. Por la tarde ha havido siesta con muchos villancicos, y tocatas de ynstrumentos, y de órgano, que hize venir de Santiago para la función. El día siguiente martes, veinte, y dos se hizo una función fúnebre, cantada por la misma música por las ánimas del Purgatorio, haviendo precedido a esto una misa solemne en acción de gracias a María Santísima en su altar de los Dolores por los muchos favores experimentados de su piedad, y protección, y no haver sucedido desgracia alguna. A esta expresada última función asistieron los más de los señores curas 140v y eclesiásticos de los días antecedentes, con lo que se finalizaron las fiestas. Las gentes que han concurrido de todas clases de más de treinta, y tres feligresías, no es fácil decirlo, ni ponderarlo, baste decir era un asombro ver tanta gente, y que siendo este sitio de los más espaciosos, y anchos de este país, andaban tropezando unos con otros ${ }^{13}$.

\footnotetext{
${ }_{13}$ AHDS, Fondo parroquial, Santa Baia de Vedra, Cofradía del Santísimo Sacramento (1742-1880), fols. $39 \mathrm{v}-40 \mathrm{v}$.
} 


\section{IDENTIDAD BARROCA: ARQUITECTURA, ORNATO E ICONOGRAFÍA}

Manuel de Leis se cruza en su trayectoria profesional con maestros de la talla de Antonio Afonsín ${ }^{14}$, Diego de Sande, Francisco de Moas, Miguel de Romay, Luis Parcero y Tomás Fontenla, pero ninguno de ellos ha dejado en su producción una huella tan profunda como Fernando de Casas y Simón Rodríguez. Junto a esta herencia, en las encomiendas de Leis hay también cabida para la originalidad y el desarrollo de un estilo propio, reconocible en su labor como tracista ${ }^{15}$. Su bagaje comienza, como tantos otros maestros, con los encargos previos a su emancipación profesional, participado, bien en solitario o en colaboración con otros artistas, en la materialización de los diseños de los dos grandes arquitectos gallegos del setecientos ${ }^{16}$, sin olvidar todos los proyec-

\footnotetext{
${ }^{14}$ Leis pudo haber recalado en un primer momento en el taller de Afonsín como aprendiz, de acuerdo con la creencia de Folgar (María del Carmen Folgar de la Calle, "Leis, Manuel de", Gran Enciclopedia Gallega, XIX, Santiago de Compostela-Gijón, Silverio Cañada, 1974, pág. 20).

${ }^{15}$ Dentro de su actividad independiente y contrastada como diseñador, esté al frente o no de las obras que traza, figura, aparte del retablo que nos ocupa, otro delineado en 1737, hoy inexistente, ejecutado por Luis Parcero para la capilla de la cofradía del Rosario del convento de los dominicos de Santiago. Le sigue, en 1740, una urna ideada para la procesión de Viernes Santo de la referida hermandad, materializada por Tomás Fontenla. Para la iglesia del colegio compostelano de la Compañía de Jesús dibuja y realiza el retablo consagrado a Santo Toribio de Mogrovejo, encargado por María Riobóo y Seijas en 1747, y en 1758 hace lo propio con el retablo mayor de la parroquial de Santa María del Camino. En los dos cuartos centrales del setecientos proyecta y ejecuta por partes el retablo de la parroquial de San Fructuoso, inclusa en la basílica compostelana: en las cuentas de Fábrica de 1728-1731 (libranzas de 1729 y 1730) se consignan 1.870 reales que quedaban por pagar de los 4.050 reales en que le fue ajustado "el primero cuerpo del retablo" (los 2.180 reales ya abonados habían salido de los fondos de la cofradía del Santísimo); en las de 1762-1763 hay un apunte de 3.300 reales satisfechos a Leis "por hacer de nueuo el medio cuerpo del retablo" y por la "composición de los angelotes"; y en las de 1766-1767 se registra una salida de 860 reales para pagar "la fábrica y echura de la custodia del retablo de la capilla mayor con los relieues y aliños que de ella se reconoze", y otra de 36 reales "por alargar la mesa del altar y la tarima", importando todas las partidas 8.246 reales (AHDS, Fondo parroquial, San Fructuso de Santiago, Fábrica (1727-1793), fols. 14v, 106r-v y 152r). Véanse más detalles al respecto de esta producción propia, J. Couselo Bouzas, Galicia artística..., págs. 354, 415, 416 y 488; Ramón Otero Túñez, "Los retablos de la iglesia de la Compañía de Santiago", Cuadernos de Estudios Gallegos, 26,8 (1953), págs. 406-408; Ramón OTERo TÚÑEZ, El legado artístico de la Compañía de Jesús a la Universidad de Santiago, Santiago de Compostela, Universidade, 1986, págs. 60-63; y María del Carmen Folgar de la Calle y Enrique Fernández Castiñeiras, "Estilos en conflicto. El encuentro de un lenguaje académico y un gusto barroco en Santa María del Camino", en Enrique Fernández Castiñeiras y Juan Manuel Monterroso Montero (coords.), Santiago, ciudad de encuentros y presencias, Santiago de Compostela, Consorcio de Santiago-Alvarellos, 2012, págs. 227-232.

${ }^{16}$ Antonio Afonsín contrata en 1721 los servicios de Leis para que le ayude en la fabricación del retablo de la capilla de la Concepción de la catedral de Santiago, siguiendo una traza de Simón Rodríguez, siendo la primera obra en la que aparece documentado. Entre 1730 y 1733 se halla ocupado, en calidad de aparejador de Miguel de Romay, y junto a una nutrida nómina de escultores, en la fabricación del retablo-baldaquino del monasterio de San Martiño Pinario, encomendado
} 
tos que se le atribuyen, tanto de su etapa de aprendizaje como del período de madure $z^{17}$.

En el retablo de Vedra ${ }^{18}$, la ausencia de banco, sustituido por un amplio y elevado estrado que facilita el avance de los soportes, y la práctica desaparición del entablamento, que queda reducido a dos tramos sobre dichos soportes, son la base del diseño arquitectónico, que por los movimientos de la planta y la indefinición de los niveles se alinea con las fórmulas de Rodríguez. Entre la mesa de altar y la cabecera se dispone la plataforma referida, una superficie holgada dotada de pedestales que sirve de asiento a las columnas y a los pilares

por los monjes a Fernando de Casas. En el trienio 1735-1737 se encuentra trabajando en el retablo mayor y los colaterales de la capilla del Santo Cristo de Conxo bajo la supervisión de Rodríguez, a quien corresponde la autoría de tales creaciones lignarias. En 1737 figura activo en la capilla compostelana de la VOT de San Francisco, materializando, junto a Moas, los retablos laterales del presbiterio, ideados probablemente por Rodríguez. Léanse los detalles de estas actuaciones en J. Couselo Bouzas, Galicia artística..., págs. 179, 415, 594 y 595; Ramón Otero TúÑEz, "El retablo mayor de San Martín Pinario", Cuadernos de Estudios Gallegos, 34, 11 (1956), págs. 229243; Ramón Otero TúÑEz, "Miguel de Romay, retablista", Compostellanum, III, 2 (1958), págs. 205-207; María del Carmen Folgar de la Calle, Simón Rodríguez, A Coruña, Fundación Barrié, 1989, págs. 70-76, 96-101 y 106; María del Carmen Folgar de la Calle, "Retablo mayor de San Martín Pinario", en Galicia no tempo, Santiago de Compostela, Xunta de Galicia, 1990, págs. $302-$ 311; María del Carmen Folgar de la Calle y José Manuel López Vázquez, "Los retablos", en Santiago. San Martín Pinario, Santiago de Compostela, Xunta de Galicia, 1999, págs. 251-262; Alberto Fernández González, Fernando de Casas y Novoa, arquitecto del Barroco dieciochesco, Madrid, Fundación Universitaria Española, 2006, págs. 226-238; y José Manuel LóPEz VázQuez, "Mentalidad barroca y plástica monástica: el conjunto retablístico de San Martín Pinario como síntesis de la ideología postridentina", en Kazimier SABIK y Elzbieta KunicKa (eds.), La cultura del Barroco español e iberoamericano y su contexto europeo, Warszawa, Uniwersytet Warszawski, 2010, págs. 427-436.

${ }^{17}$ Por asimilación formal con el retablo de Santo Toribio se le atribuye el de San Juan Nepomuceno de la iglesia de la Compañía de Santiago, del cual, en palabras de Otero, "no es estructural y decorativamente sino una réplica", por lo que, de ser así, lo llevaría a cabo hacia 1747. También se le asigna el de San Ramón de la iglesia conventual de Conxo y los mayores de la parroquial cruceña de Santiago de Gres y la estradense de San Miguel de Moreira. Para este último, según la opinión de Folgar, "dio la traza aunque luego el encargado de tallarlo introdujo modificaciones más decorativas que estructurales". Esta información ha sido tomada de R. OTERo TúÑ̃z, "Los retablos...”, págs. 406-408; R. Otero TúÑez, El legado artístico..., págs. 63-64; y M. ${ }^{a}$ C. Folgar de la Calle, "Leis...", pág. 21.

${ }^{18}$ Para una visión general de la retablística barroca española se recomienda la consulta de las investigaciones de Juan José Martín GonZÁlez, "Avance de una tipología del retablo barroco", Imafronte, 3-5 (1987-1989), págs. 111-155; Alfonso Rodríguez GutiérRez DE Ceballos, El retablo barroco, Madrid, Historia 16, 1992; Juan José MARTín GonZÁLEZ, El retablo barroco en España, Madrid, Editorial Alpuerto, 1993. Para Galicia contamos con los estudios compendiosos de María del Carmen Folgar de la Calle, "El retablo barroco gallego", Galicia no Tempo, Santiago de Compostela, Xunta de Galicia, 1991, págs. 201-220, y María Dolores Villaverde Solar, "La evolución del retablo barroco en Galicia", en Barroco iberoamericano. Territorio, arte, espacio y sociedad, Sevilla, Ediciones Giralda, 2001, págs. 763-781. 

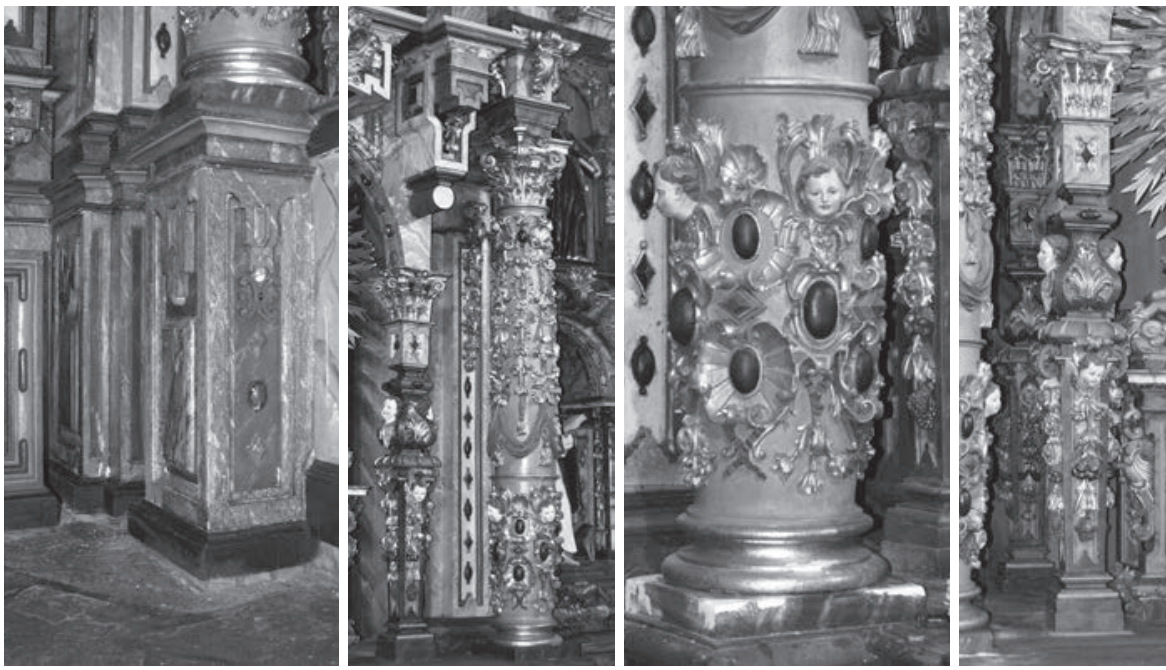

Figura 2. Santa Baia de Vedra. Retablo mayor. Pedestales.

Figura 3. Santa Baia de Vedra. Retablo mayor. Columna y pilastrón.

Figura 4. Santa Baia de Vedra. Retablo mayor. Tercio inferior de una columna.

Figura 5. Santa Baia de Vedra. Retablo mayor. Estípites.

y estípites (fig. 2). Este planteamiento estructural otorga suficiente margen para el desarrollo espacial del sector central del mueble, que acoge los dos ámbitos principales de la obra, que son el tabernáculo y la hornacina que alberga la figura de Santa Eulalia, en perjuicio de las calles laterales, en las cuales se abren cajas que sirven de marco a un santoral que se somete a la prevalencia de la mártir que da nombre a la parroquia y del lugar donde se guarda a Cristo sacramentado. Las dos columnas adelantadas, cuyos fustes poseen un anillo que separa el tercio inferior del resto de la caña ${ }^{19}$, y los robustos pilastrones cajeados situados detrás de

\footnotetext{
${ }^{19}$ La segmentación y un éntasis no muy pronunciado del fuste acerca las columnas de Vedra a la producción de Casas. El ático del retablo de la capilla de San Pedro de la catedral de Santiago, el frente de la iglesia monástica de San Salvador de Lourenzá y la fachada del Obradoiro presentan soportes con esta misma configuración, que Leis emplea también en el tabernáculo y el ático del retablo de Nuestra Señora del Camino. Acerca de estas arquitecturas pétreas y lignarias y el empleo de este elemento de sostén en el retablo barroco gallego se recomienda la lectura de José Manuel LóPEZ VÁzQuez, "Inventario e catalogación do patrimonio moble: metodoloxía e problemática", en Os profesionais da historia ante o patrimonio cultural. Liñas metodolóxicas, Santiago de Compostela, Xunta de Galicia, 1996, págs. 63-65; Iván Rega Castro, "De la columna panzuda al estípite: el retablo del Barroco en el noroeste de la Península Ibérica y las consecuencias de la Reforma católica", en Atas do IV Congresso Internacional do Barroco Íbero-Americano, Ouro Preto, C/ Arte, 2006, págs. 138-140; Alfredo Vigo Trasancos, La fachada del Obradoiro de la catedral de Santiago (1738-1750). Arquitectura, triunfo y apoteosis, Santiago de Compostela, Consorcio de
} 
ellas $^{20}$ se ubican a ambos lados de un baldaquino sustentado por estípites ${ }^{21}$, que a su vez da cobijo a un singular tabernáculo de dos cuerpos ${ }^{22}$ (figs. 3-6). El primero de ellos corresponde a un sagrario de estructura clásica, recorrido por pilastras y entrepaños, provisto de una cornisa que se adapta a la curva del nicho del pelícano y dotado de una puerta semicircular encuadrada por un marco mixtilíneo (fig. 7). El nivel superior de la custodia, anclado en una peana piramidal, semeja un viril, con su correspondiente óculo ovalado para la exposición de la Sagrada Forma, rodeado de rayos, nubes, querubines y amorcillos de cuerpo entero (fig. 8). Sobre el indicado pabellón se dispone el camarín de frente trilobulado que acoge a la imagen titular, cercado por una moldura multiforme apoyada sobre pilares rebajados y pilastras adosadas ${ }^{23}$ (fig. 9) y cubierto por un alero que reposa

Santiago-Electa, 1996; y A. Fernández GonzáLEz, Fernando de Casas..., págs. 97-102 y 253254.

${ }^{20}$ J. M. López Vázquez: “Inventario....”, págs. 60-61.

${ }^{21}$ El uso de estípites por parte de Leis es producto de su convivencia profesional con Casas y Romay, no obstante los de Vedra, que articulan asimismo el retablo de Gres, son absolutamente originales, y por lo tanto distintos a los que utiliza el arquitecto compostelano en los baldaquinos de San Martín de Santiago y la capilla de la Virgen de los Ojos Grandes de la catedral de Lugo (véanse, sobre este recinto y su retablo, María Dolores Vila Jato, Lugo barroco, Lugo, Diputación de Lugo, 1989, pág. 48; Carlos Pena Buján, "Gaude Virgo Gloriosa. Reflexiones sobre la capilla de la Virgen de los Ojos Grandes de la Catedral de Lugo", Abrente, 32-34 (2000-2002), págs. 167-190; y A. Fernández González, Fernando de Casas..., págs. 226-238). Sobre el uso de dicho soporte en la retablística gallega son de gran provecho los escritos de Marisol CerdeIra DaCasa, "La presencia del estípite en los retablos del arciprestazgo de Boborás", en En torno al arte auriense. Homenaje a Don José González Paz, Ourense-Santiago de Compostela, Diputación de Ourense-Universidade de Santiago de Compostela, 1990, págs. 161-173; J. M. LóPez VÁzquez, "Inventario...", págs. 61-63; Carmen Pérez LarRán, "El retablo de la Expectación de la catedral de Tui: la introducción del estípite en Galicia", Actas del IX congreso de novos historiadores de Galicia, Santiago de Compostela, Asociación Galega de Historiadores, 2002, págs. 35-39; Carlos Pena Buján, “¿Decoro, decoración o mera evocación? El sentido de los órdenes arquitectónicos gallegos del Renacimiento y el Barroco", Sémata, 14 (2003), págs. 413-414; e Iván Rega Castro, "Barroco de estípites en Santo Estevo de Ribas de Sil, o la incógnita acerca de los obradores benedictinos del siglo XVIII", en Juan Manuel Monterroso Montero y Enrique Fernández Castiñeiras (eds.), Entre el agua y el cielo. El patrimonio monástico de la Ribeira Sacra, Santiago de Compostela, Universidade, 2012, págs. 191-213.

${ }^{22}$ Para profundizar en el asunto de los tabernáculos del Barroco español y gallego, incluido el de Vedra, recúrrase a los trabajos de Juan José MarTín GonZÁLEZ, "Sagrario y manifestador en el retablo barroco español", Imafronte, 12 (1998), págs. 25-50; y María Dolores Villaverde Solar, "La eucaristía en el arte gallego: los sagrarios-expositores", en Francisco Javier CAMPOS Y FERNÁNDEZ DE SEVILla (coord.), Religiosidad y ceremonias en torno a la eucaristía. Actas del simposium, II, El Escorial, RCU Escorial-María Cristina, 2003, págs. 1.165-1.186.

${ }^{23}$ La morfología de esta caja, y de las que dan amparo a los bultos de San Pedro y San Pablo, es otro de los rasgos de identidad de Leis. En algunos retablos suyos, acreditados o vinculados, se abren hornacinas con esta misma disposición, ya sea en los pareados de los jesuitas compostelanos o en los mayores de las parroquiales de Santa María del Camino y Gres. 


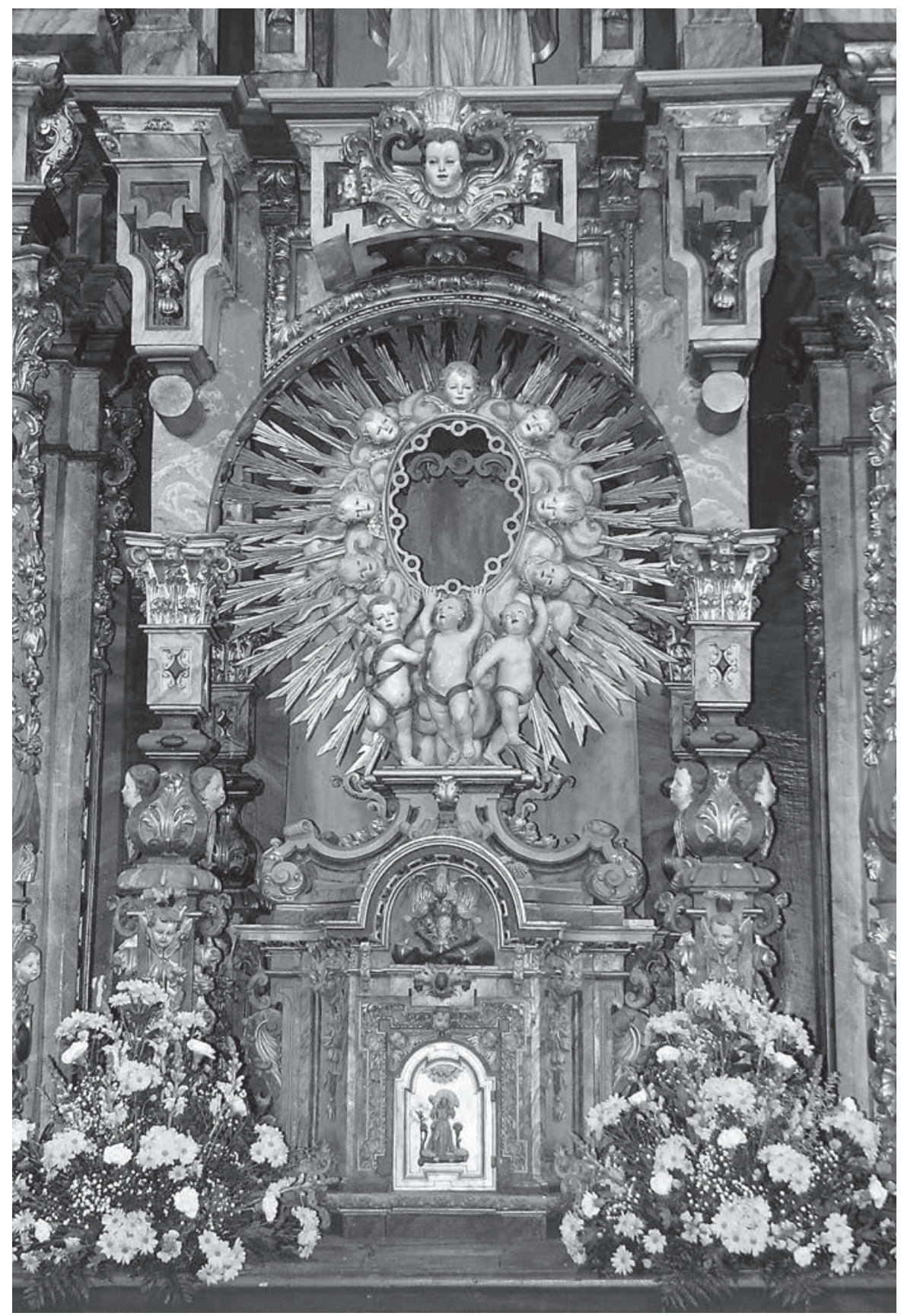

Figura 6.- Santa Baia de Vedra. Retablo mayor. Baldaquino, tabernáculo y decoración de placas. 


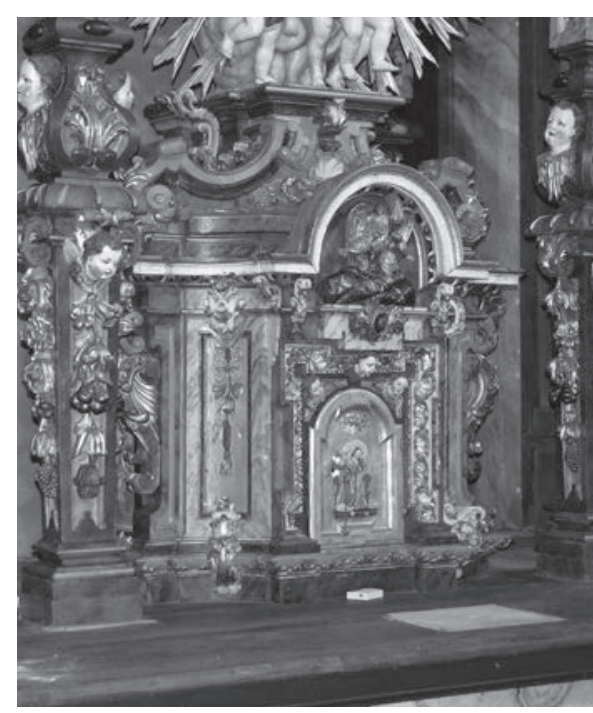

Figura 7. Santa Baia de Vedra. Retablo mayor. Sagrario.

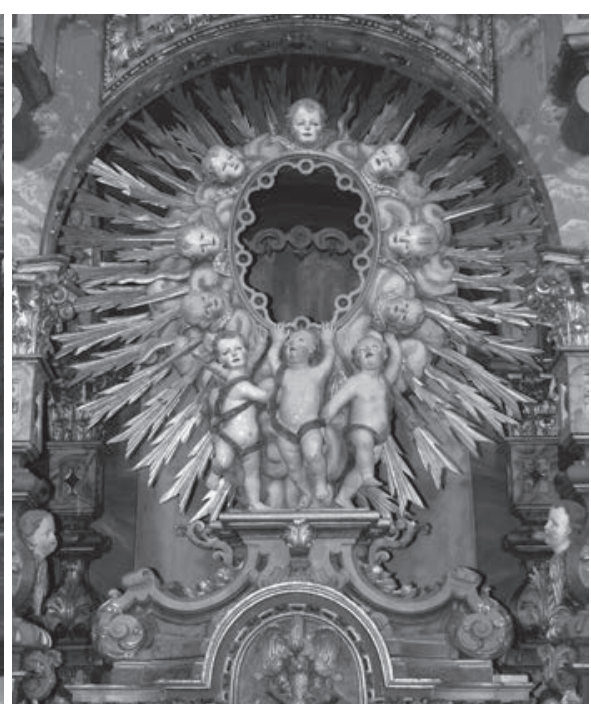

Figura 8. Santa Baia de Vedra. Retablo mayor. Expositor.

sobre cuatro machones rehundidos ${ }^{24}$. Este voladizo emerge con rotundidad de la cornisa de medio punto que cierra el retablo, la cual se enrolla en la base, receta que utiliza Rodríguez en retablos como el mayor de la iglesia de la Compañía de Jesús de Santiago de Compostela. Los extremos del mueble, posicionados en un segundo plano, albergan dos cajas de medio punto superpuestas, asentadas sobre un basamento formado por un arcón depositado sobre el pavimento de la capilla, que funciona de repisa cuando se encuentra cerrado, seguido de una predela que aloja una ménsula achaparrada ${ }^{25}$ (fig. 10). De tales hornacinas, la superior guarda afinidad formal con la de la patrona, salvo en el tipo de arco

\footnotetext{
${ }^{24}$ Leis, que emplea este recurso arquitectónico en todas sus obras, ha tenido la oportunidad de asimilarlo a pie de obra en los encargos en los que ha trabajado llevando a cabo las trazas de Rodríguez. Este es el caso de los retablos de las capillas de Prima de la catedral de Santiago, del Cristo de Conxo y de la VOT.

${ }^{25}$ El retablo de la capilla de San Pedro de la catedral de Santiago, ejecutado por Moas en 1731 (J. Couselo Bouzas, Galicia artística..., págs. 457-458, y A. Fernández González, Fernando de Casas..., págs. 97-102), y los del cuerpo de la iglesia de Vedra, materializados, y probablemente trazados, por dicho maestro, poseen ménsulas próximas a las del retablo objeto de análisis, hecho que pone de relieve la autoridad estilística ejercida por Casas sobre Moas y, por extensión, Leis. Ello podría confirmar el empleo de trazas comunes en los dos últimos retablos mayores de Vedra, materializados sucesivamente por Moas y Leis, maestros que ya habían trabajado juntos en el proceso constructivo de los retablos de los terciarios franciscanos compostelanos. Antes que en Vedra, Leis ensaya estas mismas ménsulas en los bancos de los retablos de la iglesia de la Compañía y de Santa María del Camino.
} 


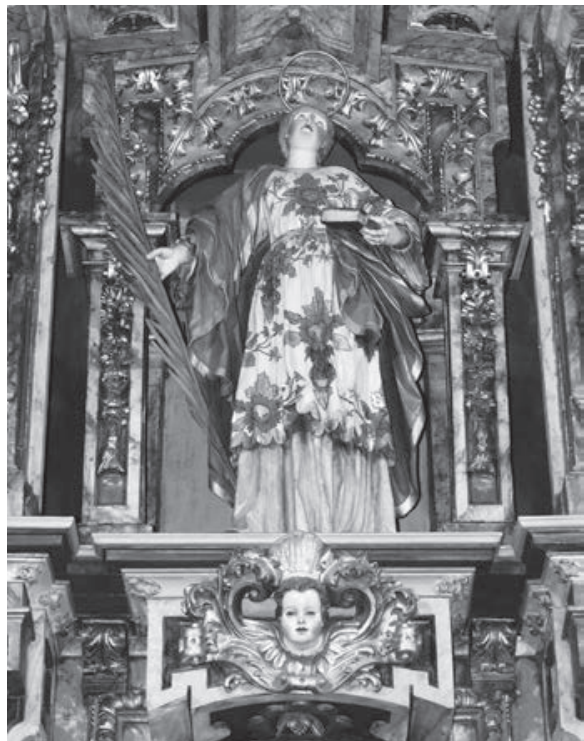

Figura 9. Santa Baia de Vedra. Retablo mayor. Hornacina e imagen de Santa Eulalia de Mérida. Entorno de Manuel de Leis (atrib.). c. 1758.

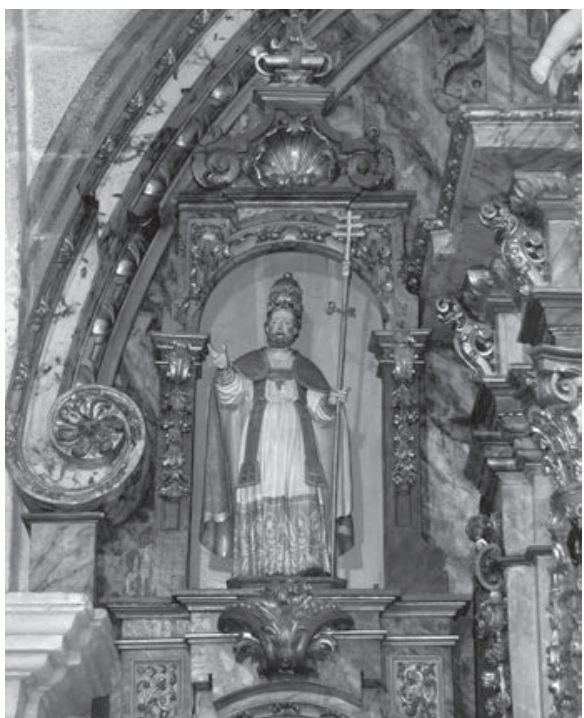

Figura 11. Santa Baia de Vedra. Retablo mayor. Nicho y figura de San Pedro. Entorno de Manuel de Leis (atrib.). c. 1758.

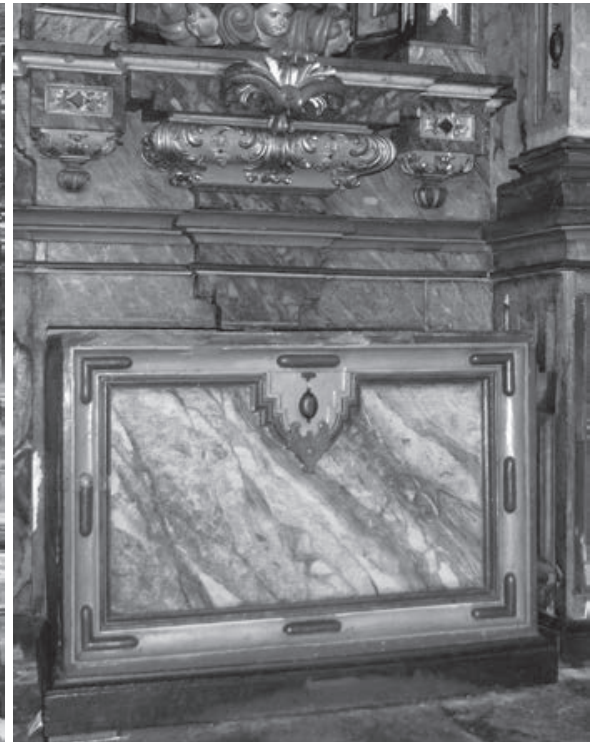

Figura 10. Santa Baia de Vedra. Retablo mayor. Baúl, repisa y predela de la calle del evangelio.

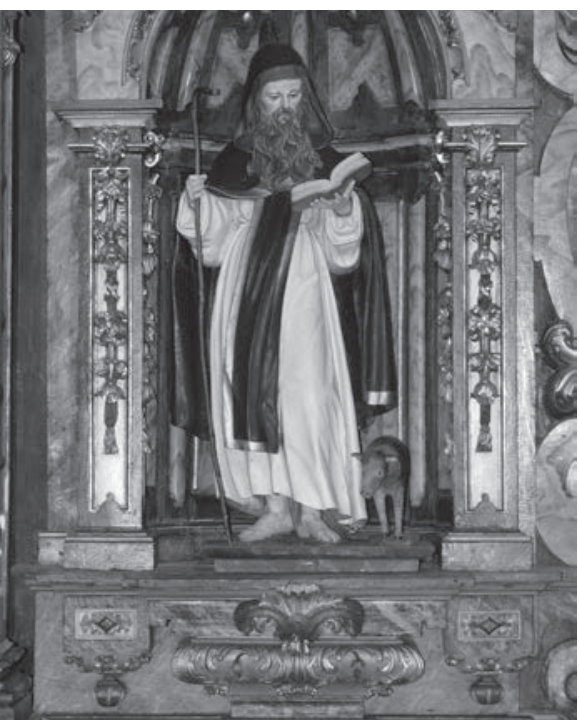

Figura 12. Santa Baia de Vedra. Retablo mayor. Caja y efigie de San Antonio Abad. Entorno de Manuel de Leis (atrib.). c. 1758. 


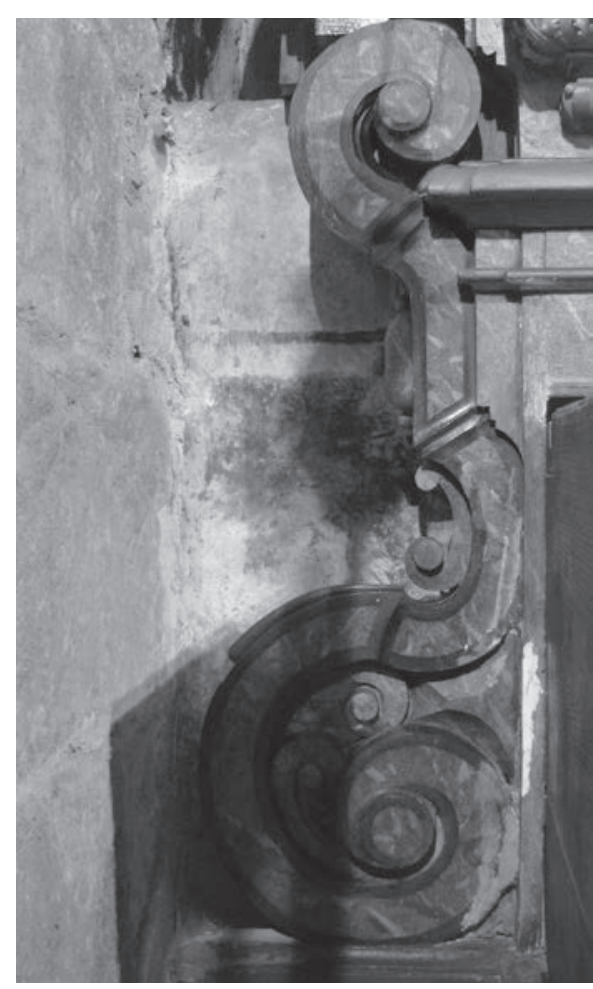

Figura 13.- Santa Baia de Vedra. Retablo mayor. Aletón inferior.

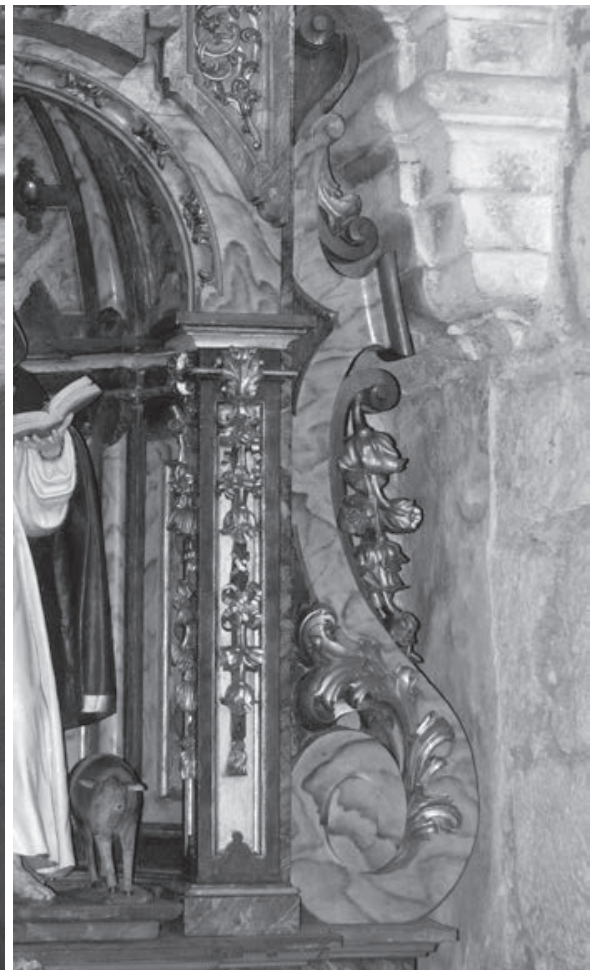

Figura 14.- Santa Baia de Vedra. Retablo mayor. Apéndice superior.

y el perfil del resalte que lo bordea (fig. 11), mientras que la de abajo, también ceñida por pilastras, es abovedada ${ }^{26}$ (fig. 12). El esquema estructural se completa con los arbotantes helicoidales que se superponen en los $\operatorname{costados}^{27}$ (figs. 13-14),

\footnotetext{
${ }^{26}$ El empleo de hornacinas conformadas por machones y terminadas en cuarto de esfera tiene su origen en Casas, con ejemplos como los retablos del transepto de San Martiño Pinario (Ramón OTERo TúÑEZ, "Los retablos del crucero de San Martín Pinario", Boletín de la Universidad Compostelana, 64 (1956), págs. 277-286), pero las de Vedra, y de igual modo las de los tres retablos compostelanos que le pertenecen (ubicados en las iglesias del colegio de la Compañía y de Nuestra Señora del Camino), presentan una segmentación interior distinta y poseen pilastrones más rotundos. Éstos y los de la hornacina de Santa Eulalia son afines a los que flanquean los nichos de los retablos laterales de Vedra, reforzándose todavía más si cabe la sospecha sobre el uso de un modelo gráfico compartido por los dos muebles fabricados en el presbiterio en los tercios centrales del siglo XVIII.

${ }^{27}$ Los apéndices arriñonados inferiores, que arrancan desde el pavimento, obedecen a un diseño que Casas utiliza, por lo que mira a su producción lignaria, en el retablo de la capilla del Pilar y, sobre todo, en el de la Azucena, ambos de la catedral de Santiago. Por el contrario, los superiores, de silueta menos recortada y más sinuosa, cuentan con referentes, aunque menos evidentes que en
} 


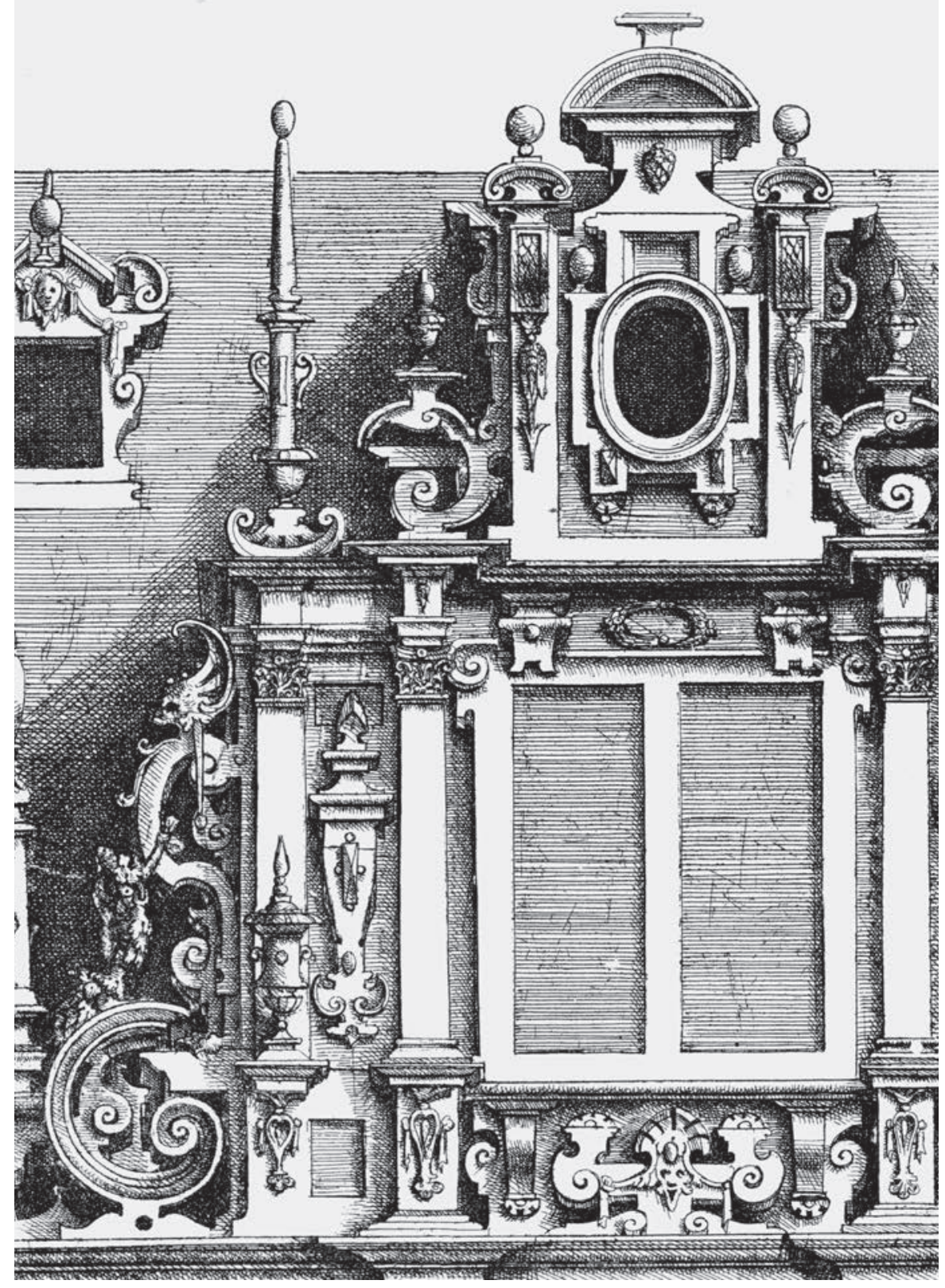

Figura 15. Wendel Dietterlin, Architectura von außtheilung, symmetria vnd proportion der fünff seulen..., Nürnberg, 1598. Grabado 191. (C) Universitätsbibliothek Heidelberg. 


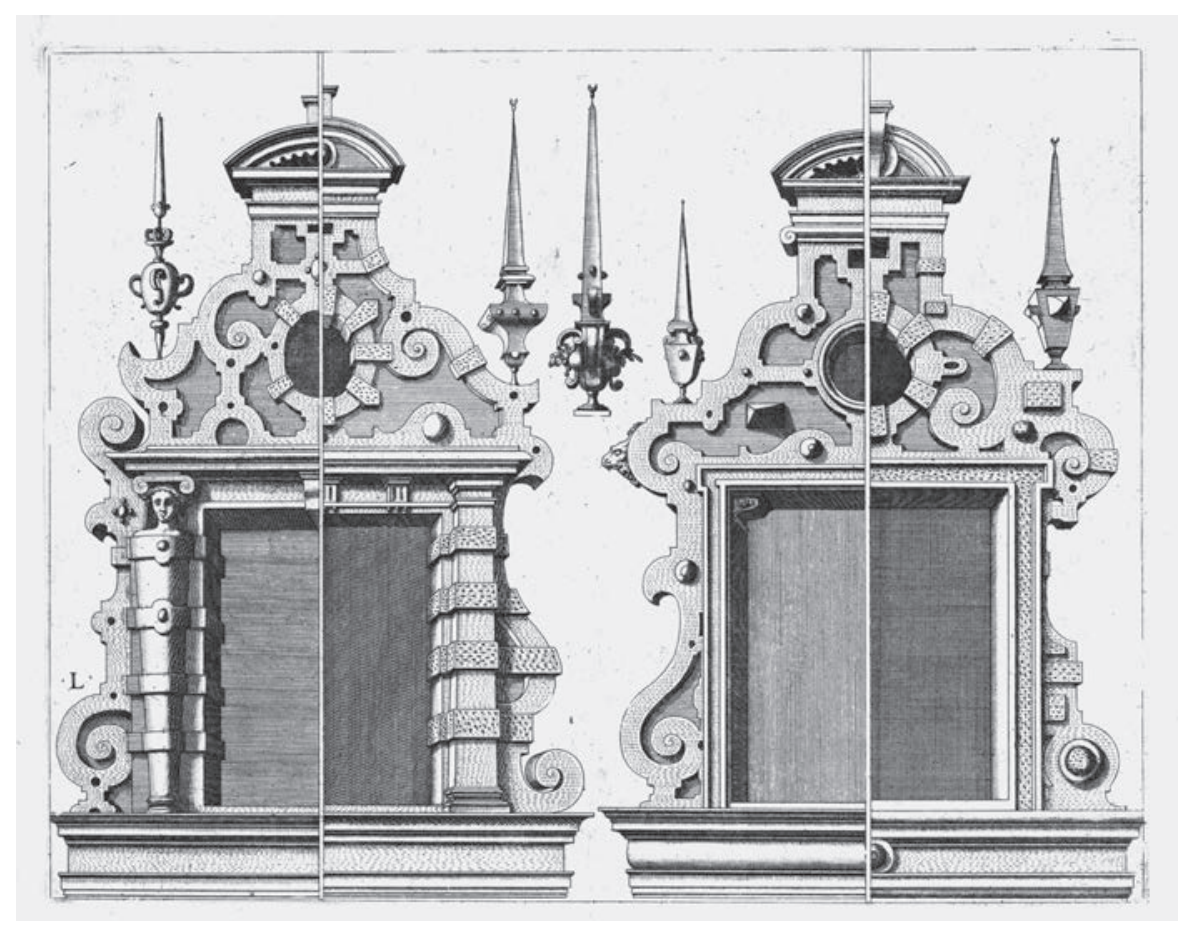

Figura 16.- Hans Vredeman de Vries, Das erst buch, gemacht auff de zwey colommen dorica und ionica..., Antwerp, 1565. Grabado L (órdenes dórico y jónico). (C) The Getty Research Institute.

las piezas enroscadas y simétricas integrados en la base del manifestador (fig. 8) y las que sirven de fundamento a los pináculos ubicados en la cima de los nichos de los apóstoles ${ }^{28}$ (fig. 11), unos y otros concebidos dentro de los postulados de Casas. Para ello, y sin detrimento de la innegable transmisión estilística, se pudieron tomar como referentes gráficos, entre otros posibles, los emblemas

los primeros, en realizaciones de Casas como la base del baldaquino trazado para la catedral de Lugo y la parte superior de la Torre de las Campanas del gran templo jacobeo, pero sobre todo en los retablos de Moas de la propia parroquial de Vedra, que Leis emplea a buen seguro como patrón, no sólo los laterales, que aún perduran, sino también el mayor, que tuvo la ocasión de contemplar antes de su retirada. Las volutas que se alzan en la cúspide de las calles laterales y las que sirven de asiento al expositor presentan una similitud más clara con las creaciones de Casas.

${ }^{28}$ Esta modalidad de pináculos, con los que Leis vuelve a experimentar en Gres, en esta ocasión como elemento claramente estructural y no decorativo, hunde sus raíces de nuevo en Casas, especialmente en su obra pétrea (fachada de la abadía de Lourenzá, claustro de la catedral de Lugo y retablo de la capilla del Pilar, por citar algunos ejemplos manifiestos). 


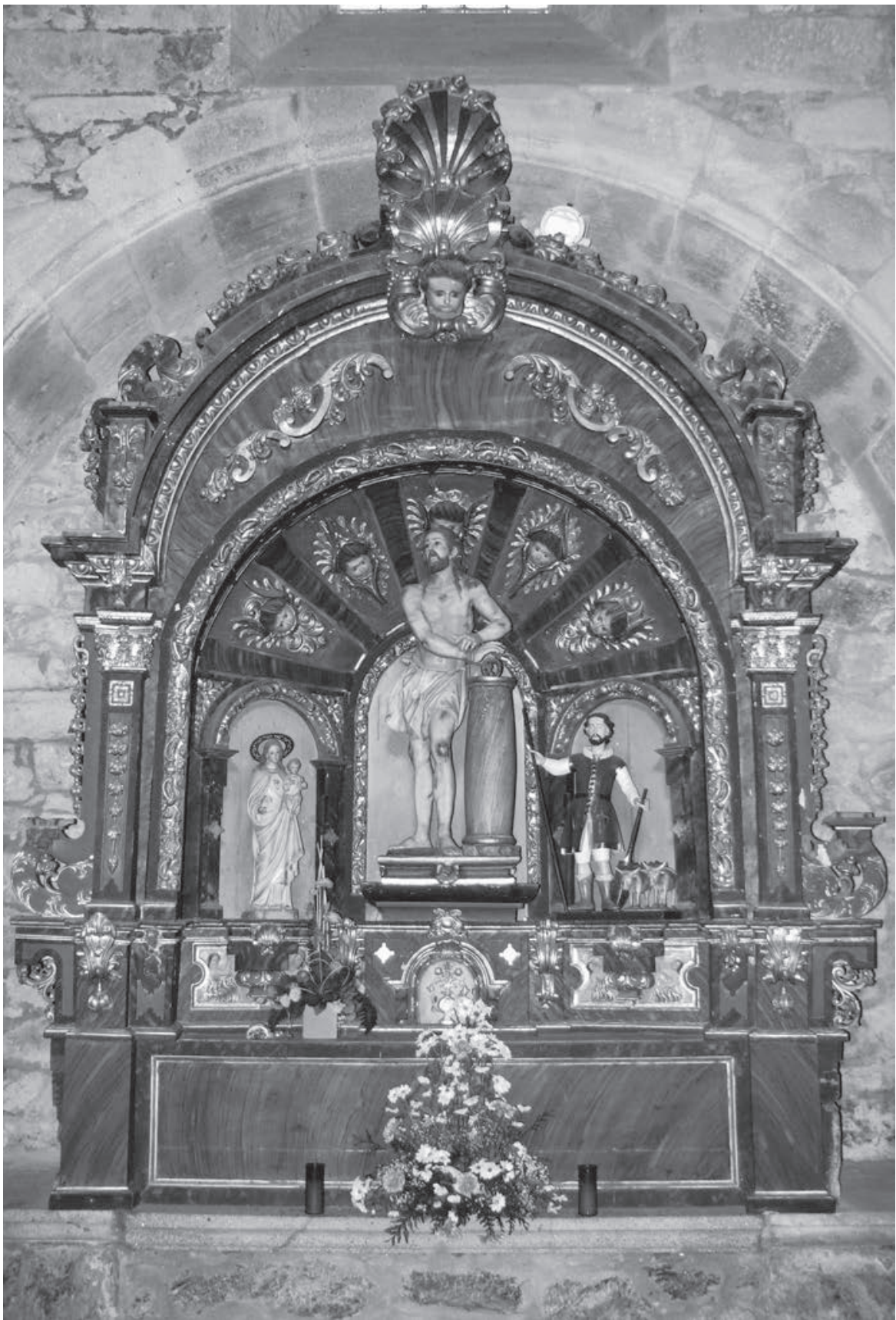

Figura 17. Santa Baia de Vedra. Retablo de la Flagelación. Francisco de Moas. c. 1744. 


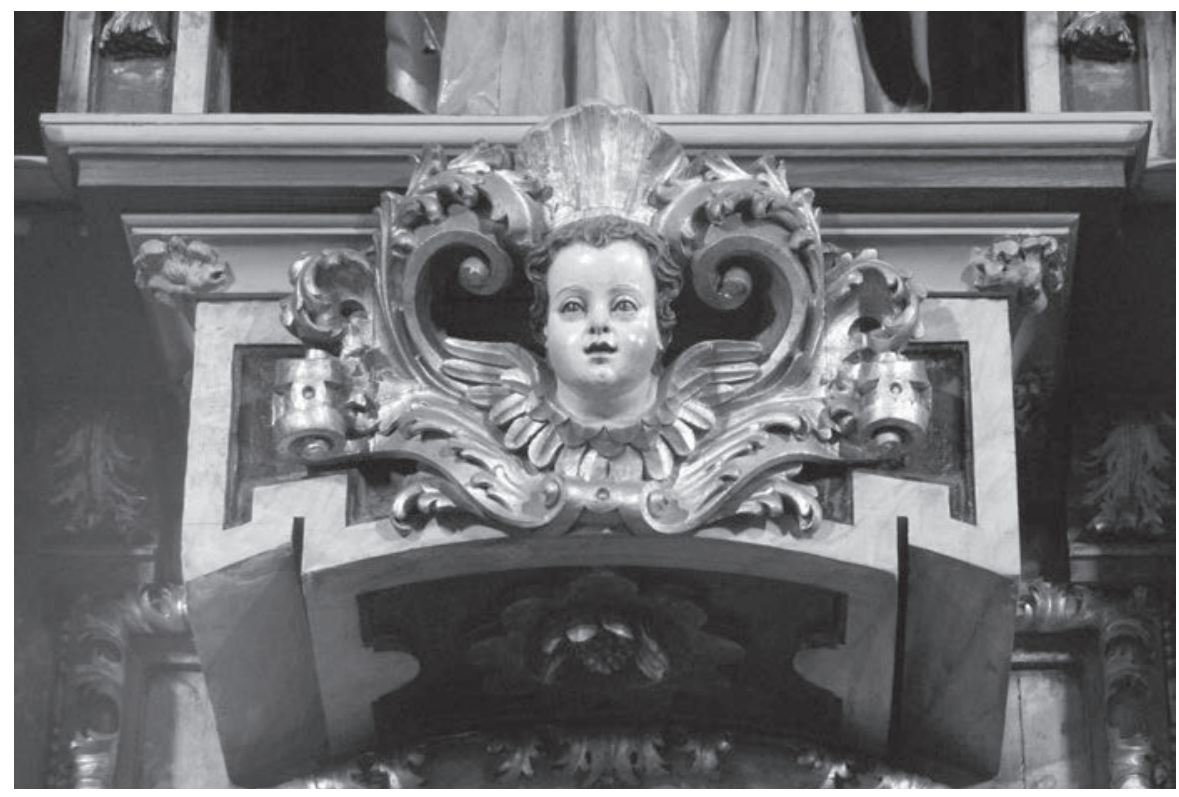

Figura 18. Santa Baia de Vedra. Retablo mayor. Cartela con querubín.

ilustrados del Flores de Miraflores del cartujo Nicolás de la Iglesia ${ }^{29}$ (fig. 27) y los grabados arquitectónicos de Wendel Dietterlin ${ }^{30}$ y Hans Vredeman de Vries ${ }^{31}$ (figs. 15-16). Salvo la aleta inferior de los costados, el resto de figuras avolutadas se mueven en la esfera estilística de los retablos de Moas en Vedra (fig. 17).

El aparato ornamental adherido a la piel de la mazonería se compone principalmente de placas de trazos y volúmenes diversos ${ }^{32}$ (figs. 2, 6 y 10), cartelas de

\footnotetext{
${ }^{29}$ Nicolás de la Iglesia, O. Cart., Flores de Miraflores, hieroglificos sagrados, verdades figuradas, sombras verdaderas del mysterio de la Inmaculada Concepcion de la Virgen y Madre de Dios Maria Señora Nuestra, Burgos, Diego de Nieua y Murillo, 1659.

${ }^{30}$ Wendel DieTterLin, Architectura von außtheilung, symmetria vnd proportion der fünff seulen, und aller darauß volgender kunst arbeit, von fenstern, caminen und epitaphien..., Nürnberg, Hubrecht und Balthasar Carmor, 1598 (grabado 191). Véase la edición facsimilar del tratado (The fantastic engravings of Wendel Dietterlin, New York, Dover Publications Inc., 1968. Introducción de Adolf K. PlaczeK), en especial la portada y los grabados 16, 17 y 191.

${ }^{31}$ Hans VRedeman de VRIES, Das erst buch, gemacht auff de zwey colommen dorica und ionica..., Antwerp, Hieronymus Cock, 1565 (grabado L de los órdenes dórico y jónico).

${ }^{32} \mathrm{Si}$ bien la mayoría de placas existentes en el retablo se emparentan con el acervo estilístico de Rodríguez, al menos una de ellas — la única que termina en un cilindro—- recortada en los ángulos del baldaquino, la usa Casas, y sólo él, en encomiendas como el retablo de la capilla del Pilar de la catedral de Santiago y la iglesia monástica de Vilanova de Lourenzá. Este cilindro no se debe confundir con el motivo circular tan habitual en los retablos y empresas arquitectónicas de Rodríguez,
} 
variado tamaño y composición (figs. 12, 18,19 y 22) y festones conformados por distintas figuras decorativas, como volutas, querubines, cintas, conchas, frutos, flores y hojas. Los óvalos y las puntas de diamante, con bolas adosadas o sin ellas, tallados en el plano de la madera a modo de piedras preciosas engastadas en esta joya lignaria ${ }^{33}$ (figs. 2-4), beben del repertorio de Vredeman ${ }^{34}$ (figs. 20 y 21).

y que el propio Leis emplea en el retablo de Gres. Sobre la capilla del Pilar y su programa decorativo véanse María Teresa Ríos Miramontes, "Estudio arquitectónico de la capilla del Pilar de la catedral de Santiago de Compostela", Archivo Español de Arte, LXI, 244 (1988), págs. 350-353; María del Socorro Ortega Romero, "A propósito del ornato de la capilla del Pilar de la catedral de Santiago: el viaje de Fernando de Casas a Portugal", Actas do I Congresso Internacional do Barroco, II, Porto, Universidade do Porto, 1991, págs. 167194; y Miguel Taín Guzmán, "Los mármoles portugueses de la capilla del Pilar de la catedral de Santiago", en Camilo Fernández Cortizo, Domingo GonzÁlez Lopo y Enrique MARTínez RodríGuez (eds.), Universitas. Homenaje a Antonio Eiras Roel, II, Santiago de Compostela, Universidade, 2002, págs. 75-76.

${ }^{33}$ Estas pequeñas figuras se localizan en mayor medida en los pedestales de las columnas, los pilares traseros, el interior de las hornacinas inferiores y el intradós del arco del tabernáculo. Están presentes en las arquitecturas leñosas diseñadas por Rodríguez y, por descontado, en el resto de encargos hechos a Leis, pero no son ni mucho menos los únicos maestros, ni los primeros, que se han valido de ellas para decorar retablos y arquitectura. Aparecen figuradas y modeladas en los paramentos pétreos de la capilla catedralicia del Pilar de Santiago, siendo ésta la primera y única vez que se verán en una obra ideada por Casas.

${ }^{34}$ Hans VRedeman de VRies, Das erst buch..., Antwerp, 1565 (grabado n. ${ }^{\circ} 3$ del orden toscano), y Architectura, oder, bauung der antiquen auss dem Vitruuius..., Antwerpie, Geerhardt de Jode, 1581 (frontispicio).

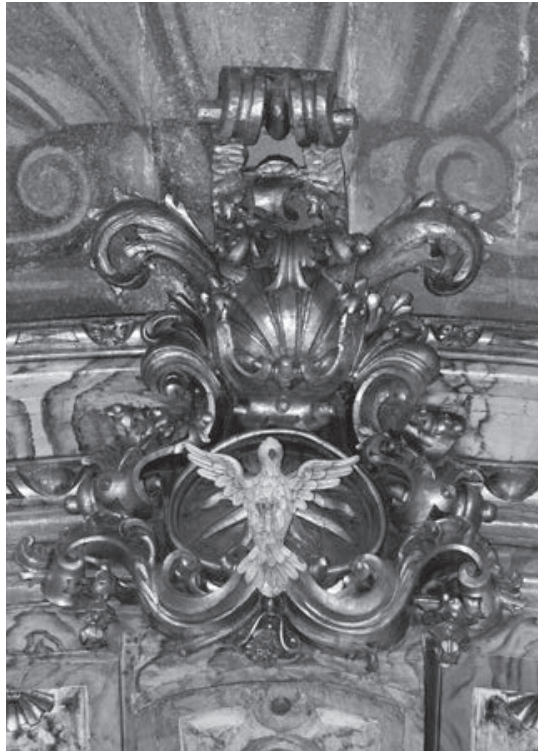

Figura 19. Santa Baia de Vedra.

Retablo mayor. Cartela con paloma.

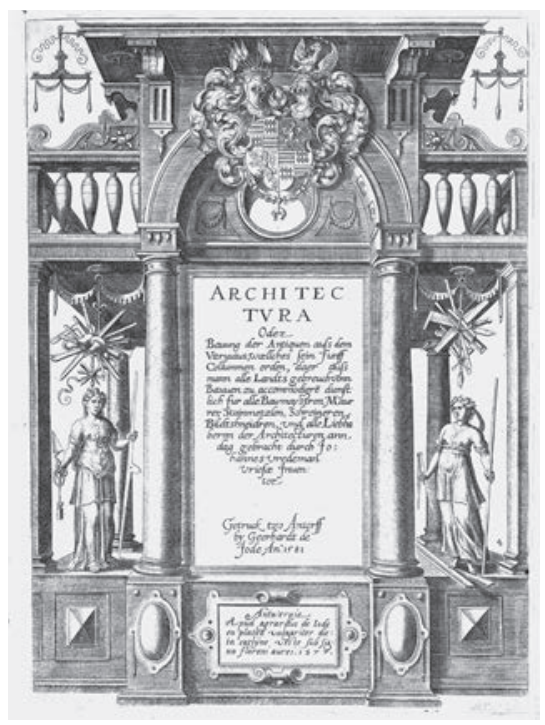

Figura 20. Hans Vredeman de Vries, Architectura, oder, bauung der antiquen auss dem Vitruuius..., Antwerpie, 1581.

Frontispicio. (c) The Getty Research Institute. 


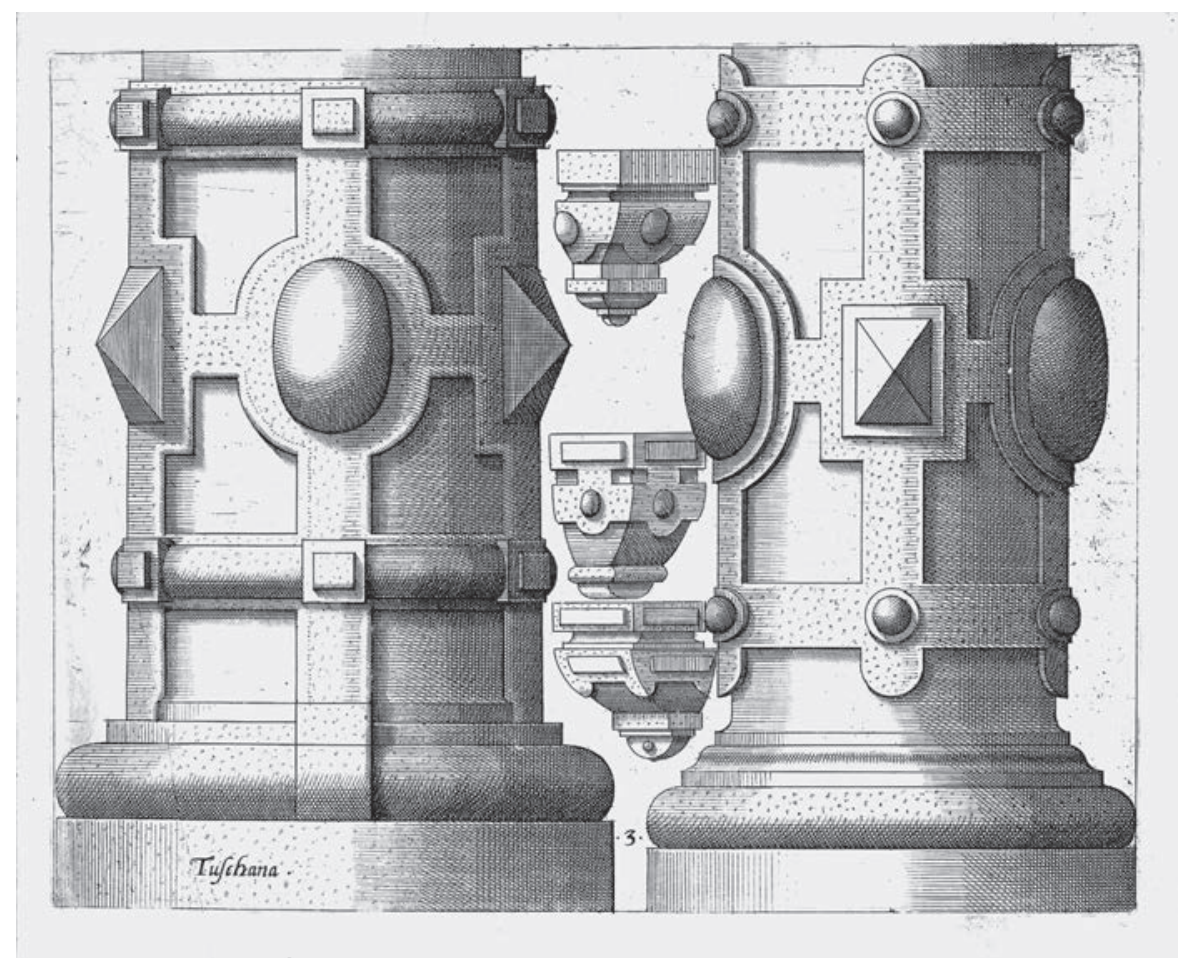

Figura 21. Hans Vredeman de Vries, Das erst buch..., Antwerp, 1565.

Grabado 3 (orden toscano). (C) The Getty Research Institute.

Pero es en el tercio inferior de las columnas donde se encuentra la contribución de Leis al ornato del retablo dieciochesco gallego, pues allí una serie de elipses rodeadas de rocalla aportan la pincelada rococó al conjunto ${ }^{35}$ (fig. 4).

El programa escultórico, incluida la corte angelical, podría imputarse al entorno de Leis, conclusión a la que se llega tras un análisis pormenorizado de

\footnotetext{
${ }^{35}$ Podemos formarnos una idea sobre los motivos ornamentales del Barroco español y sus fuentes grabadas a través de los trabajos de Alfonso Rodríguez Gutiérrez de Ceballos, "Motivos ornamentales en la arquitectura de la Península Ibérica entre Manierismo y Barroco", en España entre el Mediterráneo y el Atlántico. Actas del XXIII congreso internacional de historia del arte, II, Granada, Universidad, 1977, págs. 553-559; y, para el arte gallego de la Edad Moderna, Paula PITA GALÁn, "Extravagancias y fantasías. Estudio de las fuentes ornamentales del Barroco gallego", en María Dolores Barral Ribadulla et al. (coords.), Mirando a Clío. El arte español espejo de su historia. Actas del XVIII congreso español de historia del arte, Santiago, Universidade de Santiago de Compostela, Universidade, 2012, págs. 2049-2061.
} 
los caracteres de la imaginería ${ }^{36}$. Esta atribución, que engloba a las esculturas de Santa Eulalia, San Pedro, San Pablo y San Antonio Abad, no se extiende al bulto de Nuestra Señora del Rosario - hoy del Carmen_-, achacable al círculo de Moas. La devoción a Santa Eulalia de Mérida es una de las más antiguas y extendidas y de más rápida penetración del noroeste peninsular, remontándose al período tardoantiguo, en los albores del cristianismo primitivo ${ }^{37}$. Aquí se representa tal y como corresponde a una mártir: mujer de semblante lozano y agraciado, con la mirada extasiada en dirección el ser superior, vestida según la alcurnia que Prudencio le atribuye ${ }^{38}$, con manto, túnica y una tercera prenda superpuesta más corta. Sujeta con ambas manos la palma y el libro sagrado ${ }^{39}$, atributos que le competen por su comportamiento heroico frente a la persecución, el suplicio y la

\footnotetext{
${ }^{36}$ Ello no significa necesariamente que Leis sea el autor material, pero sí que se labrarían para el retablo del que se hace cargo, pudiendo haberlas encargado a otro maestro. Lo mismo ocurre en el caso de Moas.

${ }^{37}$ La repercusión de Santa Eulalia en la antigua Lusitania y su capital, Mérida, medio en el que nace el culto para luego expandirse, ha sido puesta de manifiesto ya en el setecientos por Enrique FlóRez, España sagrada, XIII, Madrid, Antonio Marín, 1756, págs. 266-302. Para los testimonios arqueológicos sobre la santa en Galicia, su antigüedad en el panteón gallego y el acristianamiento del noroeste peninsular contamos con los análisis de Xosé Lois Armada Pita, "El culto a Santa Eulalia y la cristianización de Gallaecia: algunos testimonios arqueológicos”, Habis, 34 (2003), págs. 365-388; y Xosé Lois Armada Pita y María Martín SeiJo, "Novidades sobre o culto a Santa Baia-Eulalia e a arqueoloxía paleocristiá no noroeste peninsular”, Larouco, 4 (2007), págs. 123-139. Por su parte, Carmen García Rodríguez, El culto de los santos en la España romana y visigoda, Madrid, Instituto Enrique Flórez, 1966, págs. 284-303, dedica su investigación a desentrañar el entramado cultual en torno a la santa extremeña en el solpor de la romanización e inicios de la Edad Media.

${ }^{38}$ Prudencio, en el himno tercero del Peristephanon, alude a su abolengo: "La casa de tus padres, arruinada en su esperanza, te sigue con sus lágrimas, y gime angustiada la nobleza de tu estirpe, porque vas a morir en la tierna flor de tu edad, tan cerca ya de esponsales y de tálamos" (Obras completas de Aurelio Prudencio, Madrid, BAC, 1981, pág. 535).

${ }^{39}$ Los trazos figurativos de Santa Eulalia han sido perfectamente dibujados por Alejandro RECIO Veganzones, "La mártir Santa Eulalia de Mérida en calendarios y martirologios, en la devoción popular y en su iconografía (siglos IV-VII)", Extremadura Arqueológica, 3 (1992), págs. 81-110; A. Recio Veganzones, "La mártir Eulalia en la devoción popular: Prudencio primer promotor de su culto, peregrinaciones, expansión de sus reliquias e iconografía (siglos IV-VII)", en IV Reunió d'Arqueologia Cristiana Hispànica, Barcelona, Institut d'Estudis Catalans, 1995, págs. 317-336; Francisco Tejada Vizuete, "Eulalia de Mérida en la literatura y en el arte. De los orígenes al siglo XVIII", en José Luis de la Barrera Antón y José María Álvarez Martínez (dirs.), Eulalia de Mérida y su proyección en la historia, Madrid, Ministerio de Cultura, 2004, págs. 111-137; María Cruz Villalón, "La iconografía de Santa Eulalia en la Antigüedad y la Edad Media", en Eulalia de Mérida y su figura histórica. Actas del congreso del XVII centenario del martirio de Eulalia, Sevilla, Fundación El Monte, 2006, págs. 241-264; y Agustín Hevia Ballina, "Santa Eulalia emeritense: su iconografía en la catedral de Oviedo", en José Miguel Lamalfa Díaz (ed. y coord.), Santa Eulalia. Mito y realidad. Figuración y hermenéutica del texto, Oviedo, Universidad, 2010, págs. 113-168.
} 


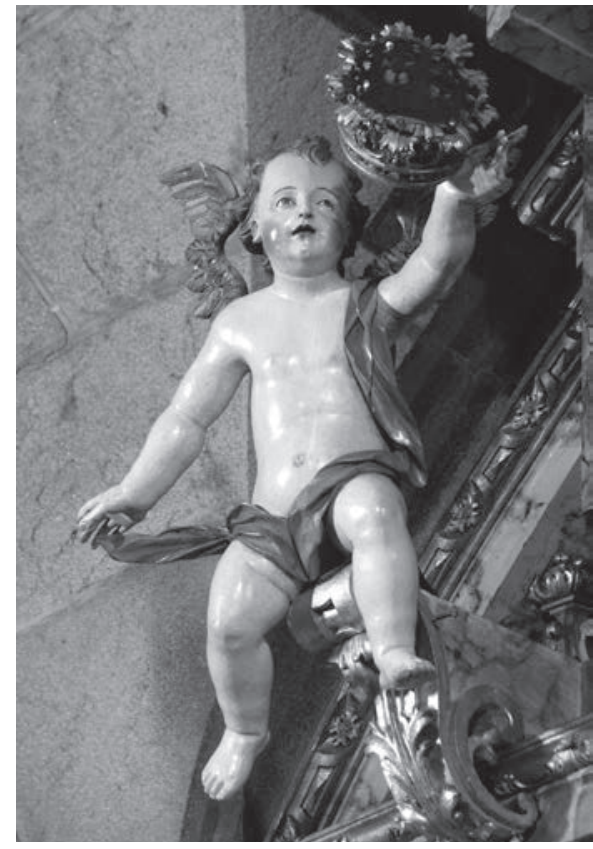

Figura 22. Santa Baia de Vedra. Retablo mayor. Ángel que entrega la corona a Santa Eulalia.

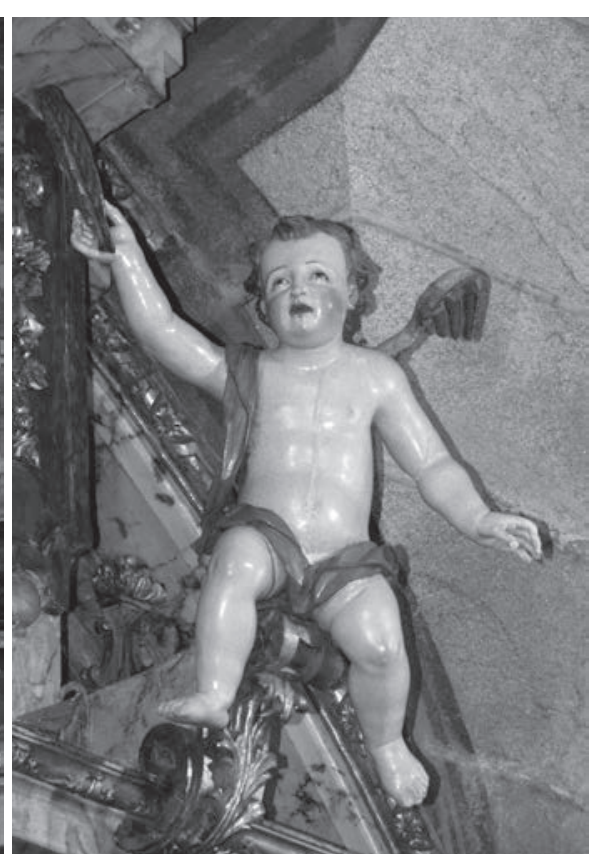

Figura 23. Santa Baia de Vedra. Retablo mayor. Ángel que ofrece la palma a Santa Eulalia.

muerte acaecida en tiempos del pretor Calpurniano ${ }^{40}$ (fig. 9). Acompañando a la invicta se hallan, sentados sobre cartelas, dos ángeles que le ofrecen los trofeos de la victoria: la corona y, de nuevo, la hoja de arecácea (figs. 22-23). La paloma mixturada con la tarjeta dispuesta en la clave del arco alude, teóricamente, a un episodio de la historia de la manceba en el que el ave brota de su boca tras consumarse su óbito $^{41}$ (fig. 19).

En un estrato inferior se sitúan los padres de la Iglesia, San Pedro y San Pablo. El converso de Tarso no se aleja ni un palmo del esquema tradicional y se efigia descalzo y con el aspecto, las vestiduras y los distintivos propios de un apóstol de Cristo. Cubre su faz con una profusa barba y el cuerpo con una túnica

\footnotetext{
${ }^{40}$ La referencia al martirio y su narración literaria se la debemos a Prudencio, pero la primera alusión a Calpurniano, dirigente que tenía a su cargo el área emeritense — según el Breviario de Évora-, figura en la passio altomedieval de Santa Eulalia. Véase al respecto Pilar Riesgo Chueca, Pasionario hispánico, Sevilla, Universidad de Sevilla, 1995, págs. 51-69.

${ }^{41}$ Así narra el poeta hispano el acontecimiento: "Súbita brota rauda de aquella boca una paloma, y, más blanca que la nieve, se la vio dejar los labios de la mártir y dirigirse a las estrellas; era ésta el alma de Eulalia, blanca como la leche, veloz, inocente". Y prosigue: "El pretor mismo contempló salir el ave de la boca de la joven a la vista de todos". Obras completas de Aurelio..., pág. 537.
} 
ceñida a la cintura y manto. Con una de sus manos sujeta el libro de las escrituras, mientras que la otra, hoy vacía, sostuvo en su momento la espada que alude a su pasado como soldado al servicio de Roma ${ }^{42}$. El príncipe de los apóstoles, por el contrario, aunque pareja necesaria de San Pablo, no se representa como cabeza de los discípulos del Mesías, como cabría esperar, sino como pontífice de la Iglesia Universal, indumentado con alba, estola, pectoral y capa pluvial. La barba de su rostro es más corta que la de su par y porta sobre su cabeza la tiara papal. Con una de sus manos aprieta el bordón cruciforme que le concierne por su dignidad, al cual se anexa una de las dos llaves que lo identifican como guardián, haciendo con la otra el gesto de bendecir ${ }^{43}$ (fig. 11).

La Virgen del Carmen, cuya efigie se posiciona en el primer nivel del mueble, en el lado del evangelio, fue en realidad una Virgen del Rosario hasta las postrimerías del segundo tercio del ochocientos ${ }^{44}$, y como tal se analiza en el presente trabajo. El cambio pudo deberse al deseo de equipar la Virgen carmelita con San Antonio Abad, su pareja en la epístola, pues ambos se destacan como mediadores de las almas del purgatorio ${ }^{45}$. La Madre de Dios se eleva sobre un trono de nubes y querubines, porta corona en su cabeza, se arropa con túnica y manto y, desde la mutación, a su indumentaria se le ha añadido un fragmento del escapu-

\footnotetext{
${ }^{42}$ Consúltense las cualidades iconográficas de San Pablo en Karl Künstle, Ikonographie der christlichen kunst, II, Freiburg, Herder, 1928, págs. 487-490; Émile MÂLE, Les saints compagnons du Christ, Paris, Editions Beauchesne, 1958, págs. 108-123; Martin Lechner, "Paulus Apostel", en Engelbert Kirschbaum (ed.), Lexikon der christlichen ikonographie, VIII, Freiburg, Herder, 1976, págs. 128-147; Angelo Penna, Dante Balboni y Mariella Liverani, "Paolo, apostolo", en Bibliotheca sanctorum, X, Roma, Cità Nuova, 1990 (1ª ed.: 1968), págs. 164-228; Louis RÉAU, Iconografía del arte cristiano, II, 5, Barcelona, Ediciones del Serbal, 1998, págs. 6-23; y Umberto Utro, "Alle origini dell'iconografia paolina", en Ottavio Bucarelli y Martín María Morales (dirs.), Paulo apostolo martyri. L'apostolo San Paolo nella storia, nell'arte e nell'archeologia, Roma, Gregorian \& Biblical Press, 2011, págs. 27-44.

${ }^{43}$ Del estudio de San Pedro vestido de pontifical se han ocupado K. Künstle, Ikonographie..., II, págs. 493-500; É. MÂLE, Les saints compagnons..., págs. 87-108; Wolfgang Braunfels, "Petrus Apostel", en E. Kirschbaum (ed.), Lexikon..., VIII, págs. 158-174; A. Penna, D. Balboni, M. Liverani y Giovanni Fallani, "Pietro, apostolo", en Bibliotheca..., X, págs. 588-650; L. RÉau: Iconografía..., II, 5, págs. 43-69; y, para el contexto del arte gallego, José Manuel García IGLESIAS, "Evocaciones artísticas de Roma en Compostela. El culto a Pedro y Pablo", en E. Fernández Castiñeiras y J. M. Monterroso Montero (coords.), Santiago, ciudad de encuentros..., págs. 45-71.

${ }^{44}$ En las cuentas de Fábrica de 1864 a 1866 se abonan 80 reales al escultor santiagués Caral (probablemente, Carral) por, entre otros arreglos, "la transformación de la Virgen del Rosario a la del Carmen" (Archivo Parroquial de Santa Baia de Vedra (APSBV), Fábrica (1843-1967), fol. 19v. Cfr. M. ${ }^{a}$ D. Villaverde Solar, Patrimonio..., vol. III, pág. 364). La conversión pudo consistir grosso modo en la incorporación del escapulario conventual a su atuendo y la sustitución del rosario por el distintivo que hoy posee.

${ }^{45}$ El rol de la Virgen como intercesora está perfectamente clarificado en Manuel Trens Ribas, María. Iconografía de la Virgen en el arte español, Madrid, Plus Ultra, 1947, págs. 378-382.
} 


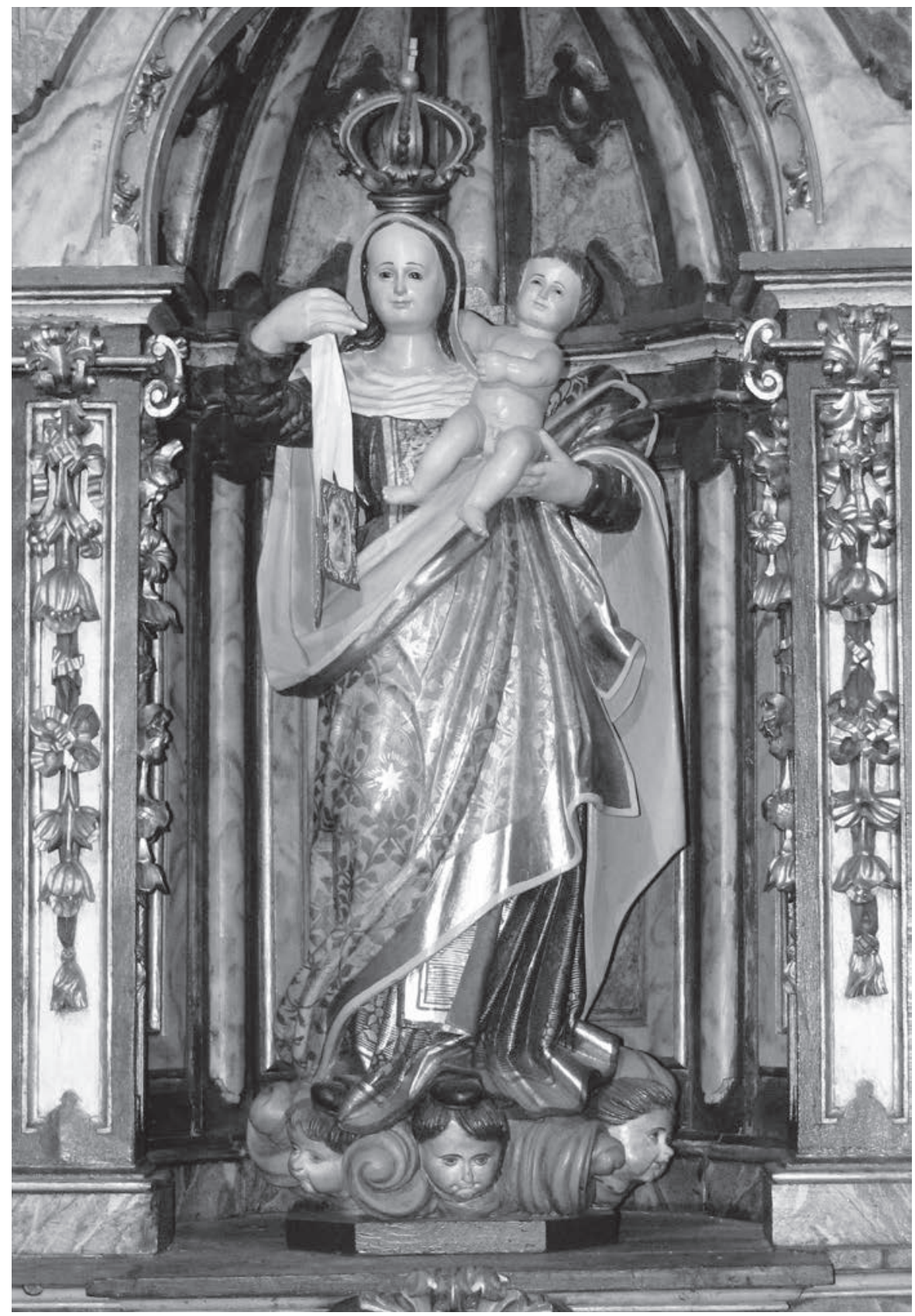

Figura 24. Santa Baia de Vedra. Retablo mayor. Imagen de la Virgen del Carmen (antes del Rosario). Entorno de Francisco de Moas (atrib.). c. 1738. 


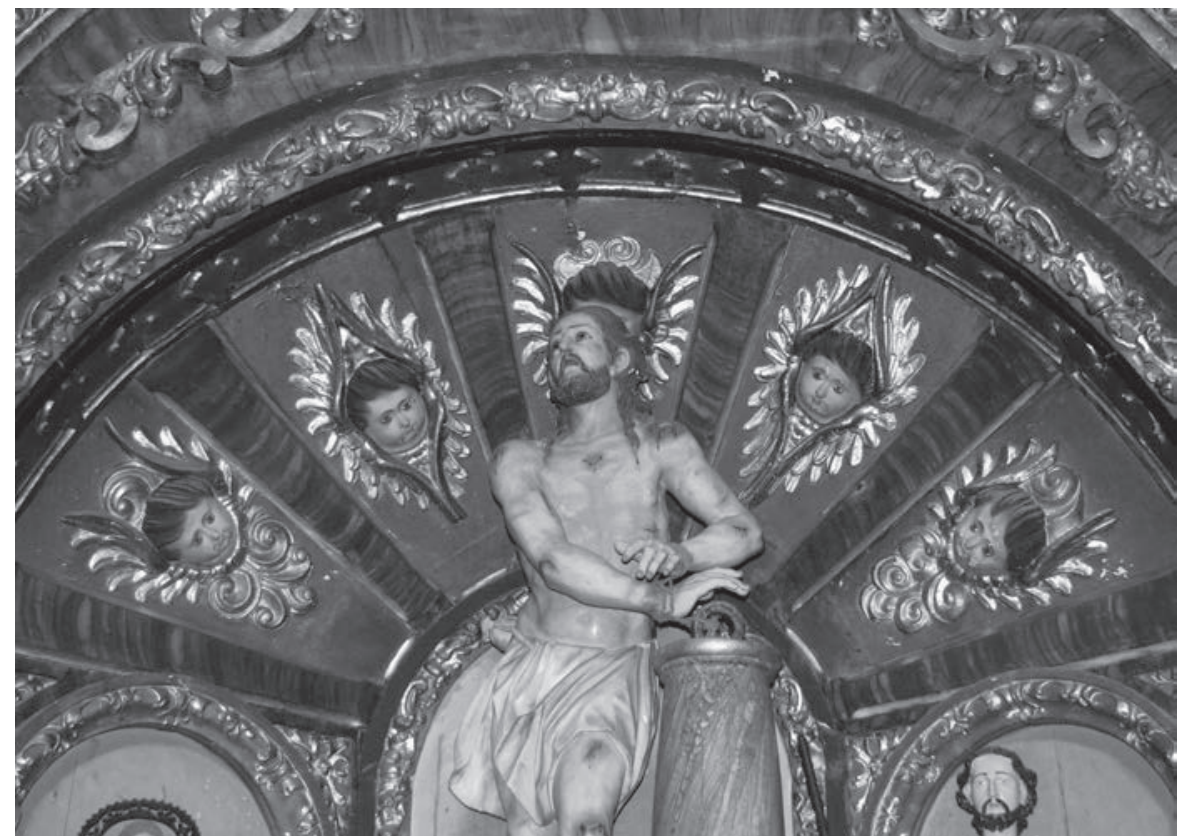

Figura 25. Santa Baia de Vedra. Retablo de la Flagelación. Querubines.

lario carmelitano. De su mano derecha levantada pende hoy la insignia de dicha advocación mariana, como en su día lo haría un rosario, y con la otra sostiene en su regazo el cuerpo desnudo de su Hijo, que con dulzura acaricia la cabeza de $\operatorname{María}^{46}$ (fig. 24). Esta es, presumiblemente, la figura con la que Pedro Figueroa obsequia a la iglesia de Vedra tras acceder al curato ${ }^{47}$, que por sus caracteres, aunque desvirtuadas a causa de un grosero repinte, puede situarse en la órbita de

\footnotetext{
${ }^{46}$ Para la iconografía de la Virgen, bajo la advocación del Rosario, véanse M. TREns Ribas: María..., págs. 282-321; Santiago Sebastián LóPEz, Contarreforma y Barroco. Lecturas iconográficas e iconológicas, Madrid, Alianza Editorial, 1985 (1ª ed.: 1981), págs. 196-207; María Dolores Díaz Vaquero, La Virgen en la escultura cordobesa del Barroco, Córdoba, Caja de Ahorros de Córdoba, 1987, págs. 109-118; L. RÉAU. Iconografía..., t. I, vol. 2, 1996, págs. 129-131; É. MÂLE, El arte religioso de la Contrarreforma. Estudios sobre la iconografía del final del siglo XVI y de los siglos XVII y XVIII, Madrid, Ediciones Encuentro, 2001, págs. 438-441; Juan Jesús LóPEZ-GuADALUPE MuÑoz, "Mito e iconografía de la Virgen del Rosario en la Granada moderna", Cuadernos de Arte de la Universidad de Granada, 37 (2006), págs. 161-178; J. J. López-GuadaluPe MuÑoz, "Iconografía de la Virgen del Rosario en el arte granadino", Communio, 39, 1 (2006), págs. 123-160; y, para Galicia, J. M. López VÁzQuez, "Tipologías de la Virgen del Rosario en el arte gallego", en V Semana Mariana en Compostela, Santiago de Compostela, Real e Ilustre Cofradía Numeraria del Rosario, 2000, págs. 111-142.

47 Véase la nota núm. 2.
} 
Moas, pues tanto el pequeño Jesús como los querubines que conforman el trono son de la misma estirpe que los alados que pueblan los retablos laterales (fig. 25). Cerca de 1744 se instituye la cofradía del Rosario en torno, supuestamente, a esta imagen, y también se inicia la fabricación del anterior retablo mayor, con el que compartiría el mismo código estilístico. A él pudo ir a parar tal figura antes del desmantelamiento del mueble, aunque en origen fuese concebida como bulto independiente, pues sólo así se comprende la implicación de la hermandad en la financiación del mueble ${ }^{48}$. Desaparecida la vieja estructura, la Virgen es reubicada en la actual y relegada a un lugar secundario, perdiendo el rango que le corresponde en el olimpo cristiano en favor del culto eucarístico, siendo ahora la cofradía del Santísimo la que se involucra en el impulso inversor de la nueva empresa.

El ermitaño San Antonio, cuyas cualidades faciales lo acercan a los santos Pedro y Pablo, especialmente en la hechura de la barba, presenta todos los componentes que constituyen el perfil usual de su iconografía: descalzo por su condición de anacoreta, arropado con la túnica blanca, el escapulario y la capa parda con capucha que distingue a los antonianos, orden hospitalaria de la que el asceta es patrón. La cabeza cubierta y la mirada concentrada en el libro que tiene abierto sobre una de sus manos otorga a San Antonio un aura de gravedad, mientras con la mano derecha agarra un cayado. Encima del burdo marrón que cubre el manto, en la parte trasera, se halla pintada la tau, alusiva al origen oriental del eremita, emblema adoptado por los miembros de la hermandad. A la izquierda, en el suelo, le acompaña su inseparable cerdo, poco reconocible a raíz de la reforma de la que fue objeto ${ }^{49}$. Con la pierna derecha replegada y estirada y la izquierda adelantada y flexionada se sugiere un movimiento y una calidad plástica que no tienen el resto de las esculturas, al menos en esa proporción ${ }^{50}$ (fig. 12). La presencia de este santo en una iglesia rural como la de Vedra tiene sentido

\footnotetext{
${ }^{48}$ Véase la nota núm. 4.

${ }^{49}$ En el trienio 1864-1866 se extraen de las arcas parroquiales 80 reales que se destinan para, entre otros cometidos, restituir "una mano a San Antonio Abad, los dedos de otra y las orejas del cerdo" (APSBV, Fábrica (1843-1967), fol. 19v).

${ }^{50}$ Sobre la iconografía de San Antonio Abad se han interesado K. KÜNSTLE, Ikonographie..., II, 1928, págs. 66-72; Henri Chaumartin, "L'image de Saint-Antoine le Grand. Essai de critique iconographique", Bulletin de la Société Française d'Histoire de la Médecine, 26 (1932), págs. 333385 y 413-441, y 27 (1933), págs. 6-14; Ekkart Sauser, "Antonius Abbas", en E. Kirschbaum (ed.), Lexikon..., V, 1973, págs. 205-217; Filippo Caraffa, Aurelio Rigoli y Maria Cirmeni Bosi, "Antonio, abate", en Bibliotheca..., II, 1990 (1ª ed.: 1962), págs. 106-136; L. RÉAU, Iconografía..., t. II, vol. 3, 1997, págs. 108-123; Laurence MeIFFret, Saint Antoine ermite en Italie (1340-1540). Programmes picturaux et dévotion, Rome, École Française, 2004, págs. 11-53; y María Rosa FerNÁNDEZ PEÑA, "San Antonio abad, un santo antiguo pero muy actual", en F. J. Campos y Fernández de Sevilla (coord.), El culto a los santos: cofradías, devoción, fiestas y arte, El Escorial, RCU Escorial-María Cristina, 2008, págs. 677-690.
} 
desde la óptica de la costumbre popular de bendecir el ganado, de ahí el acompañamiento del marrano, con más connotaciones mundanas que trascendentes ${ }^{51}$. A ello se suma su patronazgo frente a dolencias contagiosas, entre ellas la peste y la lepra, afecciones cutáneas como la sarna, enfermedades venéreas del tipo de la sífilis y, sobre todo, el ergotismo o fuego de San Antón, trastornos que se trataban de paliar en los establecimientos de curación fundados por los miembros de la orden ${ }^{52}$. Por derivación de este "fuego" somático se le tiene por abogado de los afligidos en la cárcel del purgatorio ${ }^{53}$, de ahí su supuesta equiparación con la "renovada" imagen de Nuestra Señora del Monte Carmelo.

El tabernáculo es el campo de acción preferente para la iconografía eucarística. La puerta de sagrario, sobre la que existen dudas acerca de su autenticidad barroca $^{54}$, alberga la alegoría del Buen Pastor, que es la transcripción plástica de una parábola neotestamentaria que define al Salvador como "portero" y "puerta de las ovejas" "55, por lo que su colocación en el batiente sea del todo oportuna. Cristo se halla en un ambiente campestre, ataviado con una túnica ceñida y un zurrón. Lleva sobre los hombros un cordero, metáfora del alma descarriada y rescatada que vuelve al redil de Cristo, mientras sobre la hierba se hallan otros dos, uno de ellos pastando plácidamente y el otro mirando hacia su cuidador, símbolos de la cristiandad que se mantiene fiel a las enseñanzas de la Iglesia. En el cielo se recortan las nubes y los rayos de un rompimiento de gloria ${ }^{56}$ (fig. 26). El pelícano abriéndose el pecho para revivir a sus crías con su sangre, es uno de los símbolos más recurrentes de Cristo inmolado y resucitado, que da la vida por su prole como la volátil por su nidada ${ }^{57}$ (fig. 28). En la base del sagrario y en el

${ }^{51}$ L. RÉAU, Iconografía..., t. II, vol. 3, 1997, pág. 112.

${ }^{52}$ Ibíd., págs. 111-112.

${ }^{53}$ Ibíd., pág. 112.

${ }^{54}$ J. M. García Iglesias, "Los retablos barrocos...”, pág. 637.

55 Jn 10, 1-18.

${ }^{56}$ Para un acercamiento al significado de esta encarnación sacramental acúdase a Henri LÉCLERCQ, "Bon Pasteur", en Fernand Cabrol y Henri Léclercq, Dictionnaire d'archéologie chrétienne et de liturgie, III, 2, Paris, Librarie Letouzey et Ané, 1938, págs. 2.272-2.390; y L. RÉAU, Iconografía..., t. I, vol. 2, 1996, págs. 37-39.

${ }^{57}$ Este motivo ya se hallaba en el retablo mayor existente en 1713, año en el que se pagan 11 reales a un entallador "por hazer dos pájaros de palo que se pusieron en el remate del retablo en el altar mayor, como hixos del pelícano" (AHDS, Fondo parroquial, Santa Baia de Vedra, Fábrica (17021842), fols. 19r. Cfr. M. ${ }^{a}$ D. Villaverde Solar, Patrimonio..., vol. III, 360). Sobre la representación y significación del pelícano véanse Ignacio MaLaXecheverría, Bestiario medieval, Madrid, Siruela, 1989, págs. 52-56; Juan Antonio SÁNCHEZ LóPEZ, "Iconografía e iconología del pelícano: un ensayo sobre la reconversión del concepto de filantropía", Boletín de Arte, 12 (1991), págs. 127-146; José Julio García Arranz, Ornitología emblemática. Las aves en la literatura simbólica ilustrada en Europa durante los siglos XVI y XVII, Cáceres, Universidad de Extremadura, 1996, págs. 633-656; Louis Charbonneau-Lassay, El bestiario de Cristo. El simbolismo animal en la Antigüedad y la Edad Media, vol. II, Palma de Mallorca, Olañeta, 1997, págs. 559-564; y María 


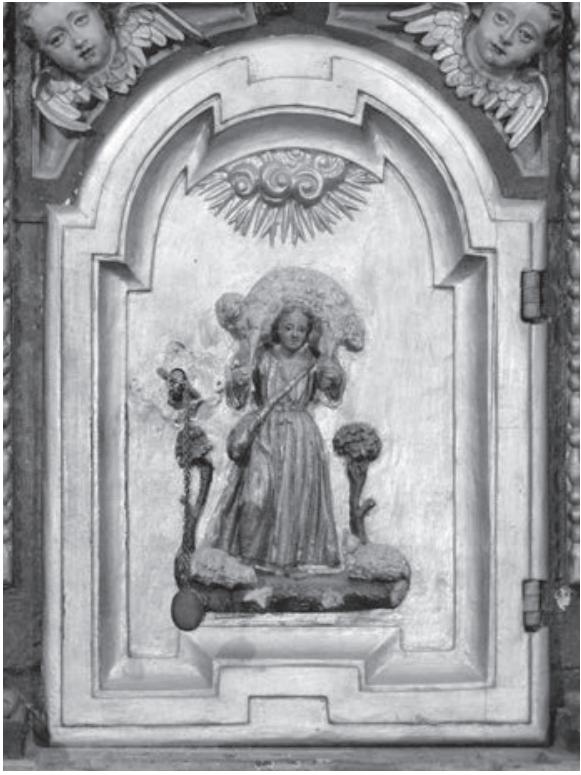

Figura 26. Santa Baia de Vedra. Retablo mayor. Puerta del sagrario y Buen Pastor.

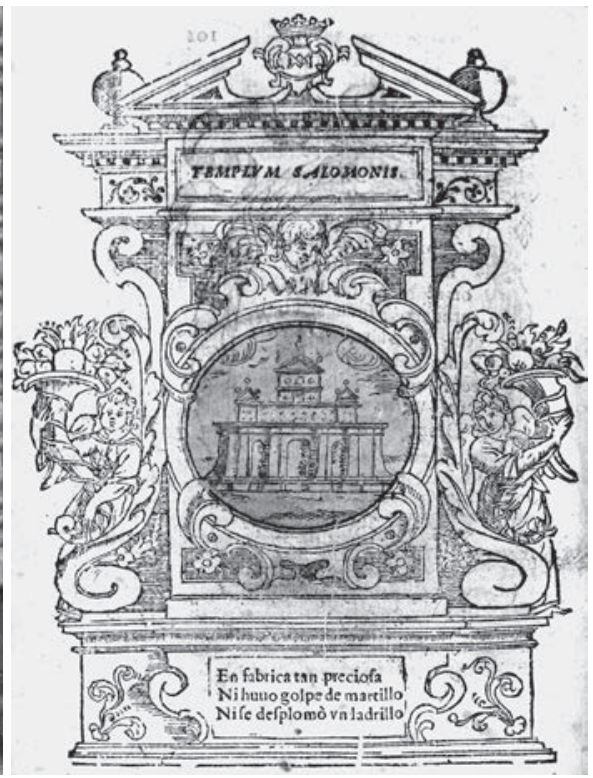

Figura 27. Nicolás de la Iglesia, Flores de Miraflores..., Burgos, 1659. Templum Salomonis. (c) Biblioteca de Castilla y León.

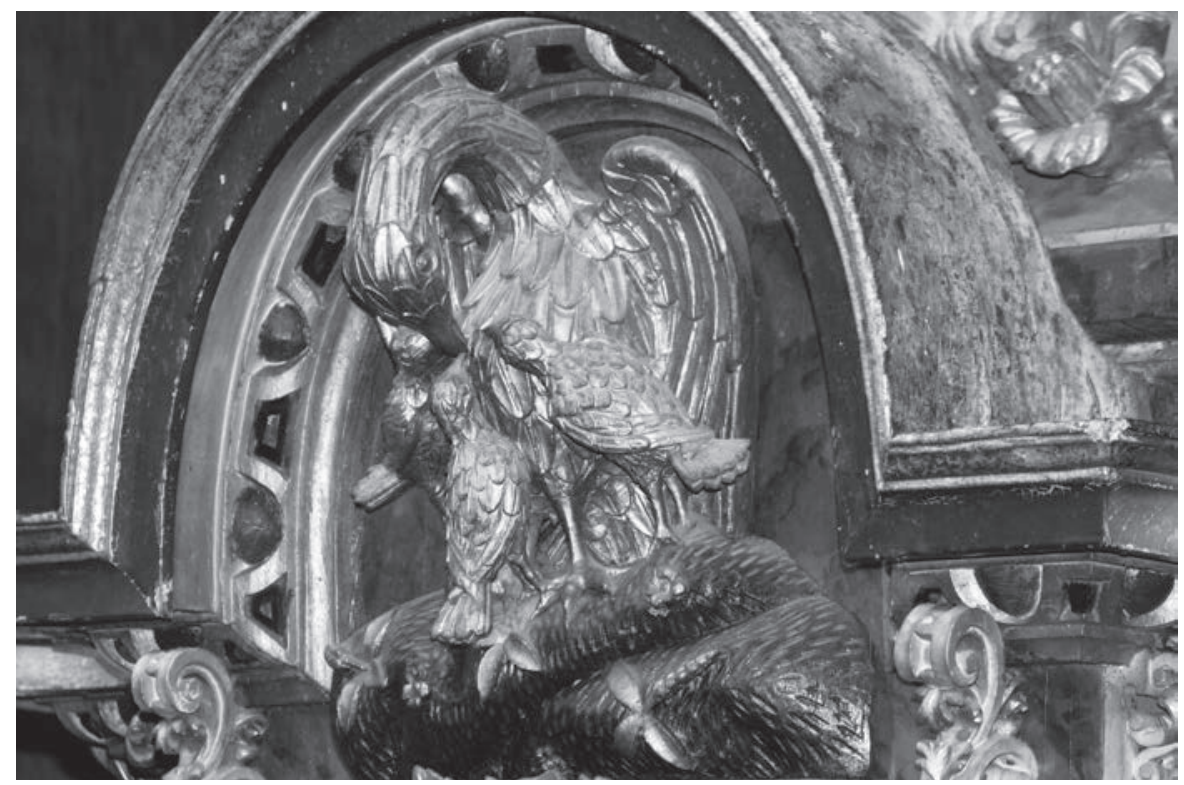

Figura 28. Santa Baia de Vedra. Retablo mayor. Pelícano. 


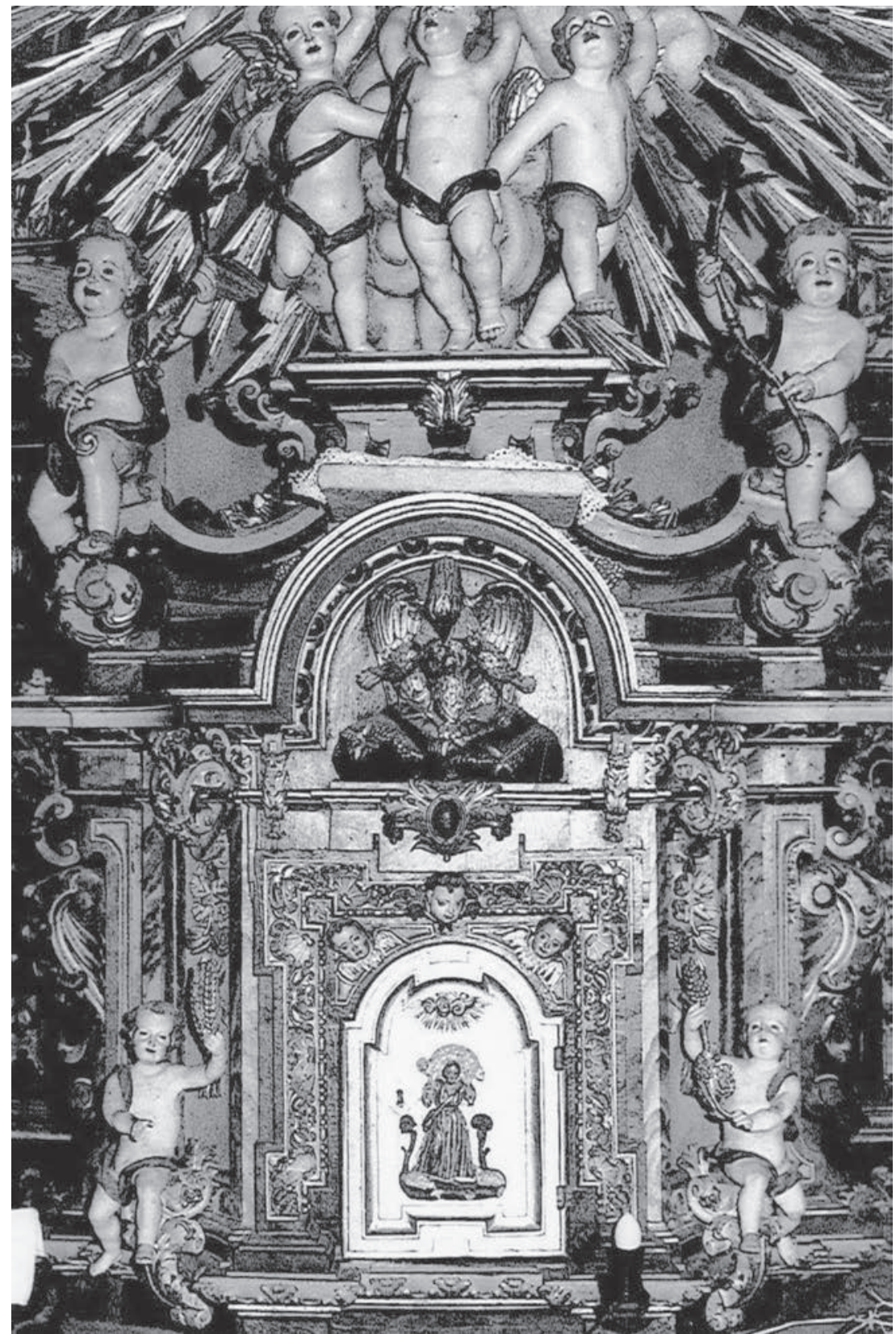

Figura 29. Retablo mayor de Santa Baia de Vedra. Sagrario antes del hurto de 1987. ( ) Arzobispado de Santiago de Compostela. AHDS, Fondo Ares Espada, sig. 47.1.6/31. Edición autorizada núm. 2-2014. 
expositor se situaban, hasta que fueron sustraídos en $1987^{58}$, cuatro pequeños ángeles en actitud sedente, dos de los cuales portaban candeleros y los otros espigas y vides, elementos simbólicos alusivos al vino y el pan transubstanciados en la sangre y el cuerpo del Salvador (fig. 29). Estas dos parejas de amorcillos comparten rasgos expresivos con el resto de espíritus alados tallados, prioritariamente, en el expositor y los soportes, e incluso con los que, elevados sobre el arco toral, tienen como cometido sujetar las lámparas de la capilla mayor (fig. 30).

\section{LA IMPRONTA DECIMONÓNICA: POLICROMÍA}

El esfuerzo monetario titánico realizado por la hacienda parroquial, las cofradías y el rector para renovar el presbiterio, la sacristía y el retablo mayor, añadido al ya realizado por el mismo comitente e instituciones con los tres retablos pagados a Moas y Barreiro, y sumado

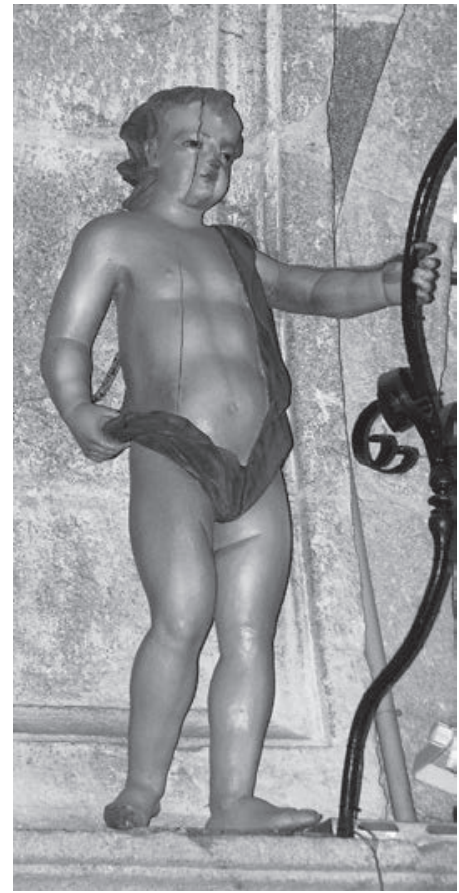

Figura 30. Santa Baia de Vedra. Capilla mayor. Ángel lamparero. al que se hará en los siguientes decenios con la total remoción del cuerpo, la fachada y la torre de la iglesia deja exhaustas por espacio de un siglo las arcas de la feligresía. La primera capa general de

\footnotetext{
Dolores Castro JimÉnez, “Amor filiorum: el ejemplo del pelícano”, en Beatriz Antón Martínez y María José Muñoz Jiménez (coords.), Estudios sobre florilegios y emblemas. Manet semper virtus odosque rosae, Valladolid, Universidad, 2011, págs. 109-118. El Fisiólogo griego dice que el pelícano "sobresale sobre todas las aves en el amor a la prole. La hembra se echa en el nido, custodiando a sus polluelos, les da calor y los abraza y llega a herirles con sus excesivas caricias, hasta el punto de perforar sus costados y morir aquéllos. Transcurridos tres días llega el pelícano macho y encuentra muertos a los polluelos; se angustia sobremanera y arrebatado de dolor golpea su propio costado y lo taladra y fluye la sangre que, gota a gota, deja caer sobre las heridas de los polluelos muertos, los cuales, de esta manera, son devueltos a la vida", y en un ejercicio de parangón de esta ave con el Mesías argumenta la metáfora: "Así Nuestro Señor Jesucristo, cuyo costado atravesó una lanza, y del que brotó al instante sangre y agua, derramó su sangre sobre sus hijos muertos, esto es, Adán y Eva y el resto de los profetas y sobre todos los muertos, e iluminó el universo mundo, y trajo aquéllos a la vida de nuevo mediante los tres días de su sepultura y su resurrección" (S. SEBASTián LóPEZ, El Fisiólogo atribuido a San Epifanio, seguido de El bestiario toscano, Madrid, Tuero, 1986, págs. 53-54).

${ }^{58}$ Véase este dato en J. M. García IgLesias, "Los retablos barrocos...”, pág. 631.
} 
color y oro administrada al retablo data de 1865, ejecutada durante el sacerdocio de Ramón Morgade Mariño, según confirman los libros parroquiales ${ }^{59}$ y una inscripción que se vislumbra tras un nefasto repinte. Andrés Cardama, pintor santiagués a quien el párroco confía esta magna empresa cercana a los 11.000 reales, tuvo el acierto de asimilar la policromía a la edad del retablo, retomando cien años después, y sin apenas mermas de calidad, la tradición del fructífero taller de policromía dieciochesca compostelana, liderado por, entre otros maestros, Juan de Castro, Bartolomé Barreiro, Francisco Sánchez, Domingo Uzal, Juan Calviño, el aludido Andrés Barreiro e incluso Juan García de Bouzas ${ }^{60}$. En los últimos diez años del diecinueve y el primer cuarto del novecientos se llevan a cabo pequeñas actuaciones en el campo de la policromía en el tabernáculo y la nómina de figuras distribuidas por el retablo ${ }^{61}$. La segunda pátina cromática sustancial que recibe el mueble es un desafortunado repinte que la documentación parroquial silencia, aunque se sabe por testigos oculares que a mediados del siglo XX el mueble fue objeto de una desacertada intervención pictórica que tuvo un fuerte impacto en el mismo, hasta tal punto que no resulta fácil advertir qué partes pertenecen a la campaña del siglo XIX y cuáles a la centuria posterior. El obrador que llevó a cabo la última de ellas ha sido escasamente respetuoso con la conservación de lo ya pintado, sin hablar de un manifiesto desconocimiento sobre la degradación natural de los colores al replicar unas gamas que han entendido como originales, pero que en realidad habían sufrido un proceso lógico de

\footnotetext{
${ }^{59}$ El precio de de esta empresa pictórica se paga con los alcances — beneficios — de la Fábrica parroquial y las cofradías, liquidados en 1866. La cofradía del Santísimo aporta 1.621,16 reales, 200 de los cuales, "sobrantes de la pintura del altar mayor", se le devuelven al poco tiempo (AHDS, Fondo parroquial, Santa Baia de Vedra, Cofradía del Santísimo Sacramento (1742-1880), fols. 179v y 181r). La del Rosario se desprende de 1.603,05 reales, cuyo importe no figura en el libro de la cofradía; y la de San Ciprián y San Roque de 2.141,20 reales, sin que quede tampoco constancia en el archivo de la cofradía (Archivo Parroquial de Santa Baia de Vedra (APSBV), Fábrica (1843-1967), fol. 17r). La Fábrica, por su parte, participa con dos cuotas, una de 1901,27 reales y otra de 3.873,70 reales (APSBV, Fábrica (1843-1967), fols. 11v y 16r). En todos los casos se entregan "para cuenta de la pintura del altar mayor de la yglesia parroquial".

${ }^{60}$ J. Couselo Bouzas, Galicia artística..., págs. 219-221, 257, 375-381, 606-608 y 637-639.

${ }^{61}$ En las cuentas de 1894 figura un apunte de 80 reales abonados de nuevo a Cardama por "dorar al temple el sagrario y en él la imagen del Divino Pastor" (cfr. M. ${ }^{a}$ D. Villaverde Solar: Patrimonio..., vol. III, pág. 364), y otro de 70 reales, entregados al pintor Rafael Raviña por "pintar, restañada, la imagen del Carmen en el retablo principal" (APSBV, Fábrica (1843-1967), fol. 54v). En 1896 se practica un último desembolso de 240 reales a favor de Cardama por pintar de nuevo la figura de Santa Eulalia, que previamente se había reparado, incrementados en otros 20 reales que costó traer "desde Santiago la imagen susodicha" (APSBV, Fábrica (1843-1967), fol. 55v). En 1923 se retribuyen con 15 pesetas los servicios de un carpintero para, entre otros encargos, "arreglar el sagrario del altar mayor para poder dorarlo", y acto seguido otras 40 pesetas a Jesús Mougán "por pintar y dorar en su interior el sagrario del altar mayor" (APSBV, Fábrica (1843-1967), s.f. Cfr. M. ${ }^{\text {a }}$ D. Villaverde Solar, Patrimonio..., vol. III, pág. 364).
} 
transformación tonal debido al transcurso del tiempo. Esto es lo que ha pasado, por ejemplo, con el azul aplicado por Cardama a las superficies lisas de las columnas, siguiendo la tradición de la escuela compostela del Barroco, y que por la inexorable decoloración se ha vuelto verde.

A la fase "neobarroca" 62 podría pertenecer la práctica totalidad del laminado áureo; el rojo de, al menos, los paños de los ángeles, las colgaduras de las columnas y uno de los laminados que recorren el cierre; el blanco de, por ejemplo, los machones de las hornacinas de la parte baja y los pilares ubicados detrás de las columnas; los marmoleados de mejor factura, elaborados con diversas gradaciones de ocre, gris, rosa y verde, repartidos por, entre otras superficies, el frente de los baúles, los tramos de predela de las calles laterales, la parte superior del baldaquino y los espacios lisos dispuestos a ambos lados de la caja de Santa Eulalia; el jaspeado agranatado de los estribos acaracolados inferiores, las placas de los bancos de los extremos y la banda lisa de la cornisa superior, siendo en este caso de tonalidades más claras; y el pequeño tesoro que representan las corlas fulgentes ${ }^{63}$ que cubren los frutos que decoran los estípites, que se han podido

${ }^{62}$ No aludiré al cromatismo subyacente sino sólo el que ya estaba a la vista antes de iniciar la restauración y el que ha quedado al descubierto tras la misma, a pesar de contar con los informes, el material gráfico y las indicaciones de las restauradoras, pues incluso ellas albergan dudas sobre su verdadero alcance por el limitado número de catas que han podido realizar. Aventurar una hipótesis resulta muy arriesgado, teniendo en cuenta además la falta de homogeneidad en las sucesivas actuaciones, pues hay zonas que únicamente tienen una lámina cromática mientras otras poseen varias, incluida la capa de preparación. Ésta es en ocasiones un finísimo revestimiento y en otras un enyesado y embolado en toda regla, sin hablar de las superficies que carecen de estucado bajo la pintura.

${ }^{63}$ Para profundizar sobre las corladuras y el resto de técnicas heredadas de la policromía barroca podemos echar mano de algunos trabajos clásicos, redactados por historiadores del arte, y de otros más actuales, escritos preferentemente, aunque no en exclusiva, por profesionales de los distintos campos de la restauración. Todos son válidos para conocer los procedimientos del dorado y de la pintura sobre madera en la generalidad del territorio español. Son los de María Elena Gómez Moreno, La policromía en la escultura española, Madrid, Escuela de Artes y Oficios Artísticos, 1943; Juan José Martín GonZÁLez, "La policromía en la escultura castellana", Archivo Español de Arte, 26, 103 (1953), págs. 295-312; Domingo Sánchez-Mesa Martín, Técnica de la escultura policromada granadina, Granada, Universidad, 1971; Pedro Echeverría GoÑI, Policromía renacentista y barroca, Madrid, Historia 16, 1992; Enriqueta GonZÁLEZ-Alonso Martínez, Tratado del dorado, plateado y su policromía. Tecnología, conservación y restauración, València, Universitat Politèctica, 1997; Luis CRISTóBAL ANTón, "Conservación y restauración de escultura y retablos en madera policromada", en Actas de los XI Cursos Monográficos sobre el Patrimonio Histórico, Santander-Reinosa, Universidad de Cantabria-Ayuntamiento de Reinosa, 2001, págs. 167-186; Fernando Rufino Bartolomé García, La policromía barroca en Álava, Vitoria, Diputación de Álava, 2001; Juan Jesús LóPEZ-GuAdalupe MuÑoz, "Retórica y color. Sobre la policromía en los retablos barrocos", en Barroco iberoamericano. Territorio, arte, espacio y sociedad, Sevilla, Ediciones Giralda, 2001, págs. 713-729; Rocío BRUQUeTAS GaLÁN, Técnicas y materiales de la pintura española en los Siglos de Oro, Madrid, Fundación de Apoyo a la Historia del Arte Hispánico, 2002; Policromia. A escultura policromada religiosa dos séculos XVII e XVIII. Estudo comparativo das 
recuperar tras la intervención, mientras que las existentes en el suelo del pelícano y los óvalos de las columnas se hallan muy degradadas o son irrecuperables.

El repinte del veinte, realizado sobre el revestimiento pictórico decimonónico, es fácilmente reconocible por la paleta grosera de azules, verdes y marrones, ya sea a través de colores planos o de los mármoles simulados, entre otros espacios, en los aletones superiores. Las zonas de mayor incidencia son los nichos abovedados, los apéndices avolutados más elevados, el sagrario, la base del expositor, los estípites y las columnas. Mención aparte merece el plan iconográfico pues a diferencia de San Pablo, cuya primera, y única, imprimación se retrasa casi con toda seguridad hasta este momento, el resto de las efigies presenta dos capas en anatomías, atuendos y atributos, con la posibilidad de que la Virgen del Carmen cuente con uno más, pues si se tratase de la imagen donada por Pedro Figueroa, como así creo, habría que sumarle a las imprimaciones de la edad contemporánea lo que quedare de la pátina barroca que mencionan las fuentes.

\section{BIBLIOGRAFÍA}

Armada Pita, Xosé Lois, "El culto a Santa Eulalia y la cristianización de Gallaecia: algunos testimonios arqueológicos", Habis, 34 (2003), págs. 365-388.

Armada Pita, Xosé Lois y Martín Seijo, María, "Novidades sobre o culto a Santa Baia-Eulalia e a arqueoloxía paleocristiá no noroeste peninsular", Larouco, 4 (2007), págs. 123-139.

Bartolomé García, Fernando Rufino, La policromía barroca en Álava, Vitoria, Diputación de Álava, 2001.

Bibliotheca sanctorum, II y X, Roma, Cità Nuova, 1962 y 1968.

Bruquetas Galán, Rocío, Técnicas y materiales de la pintura española en los Siglos de Oro, Madrid, Fundación de Apoyo a la Historia del Arte Hispánico, 2002.

Cabrol, Fernand y Léclercq, Henri, Dictionnaire d'archéologie chrétienne et de liturgie, III, 2, Paris, Librarie Letouzey et Ané, 1938, págs. 2.272-2.390.

Castro Jiménez, María Dolores, “Amor filiorum: el ejemplo del pelícano”, en Antón Martínez, Beatriz y Muñoz Jiménez, María José (coords.), Estudios sobre florilegios y emblemas. Manet semper virtus odosque rosae, Valladolid, Universidad, 2011, págs. 109-118.

Cerdeira Dacasa, Marisol, "La presencia del estípite en los retablos del arciprestazgo de Boborás", en En torno al arte auriense. Homenaje a Don José González Paz, Ourense-Santiago de Compostela, 1990, Diputación de Ourense-Universidade de Santiago de Compostela, págs. 161-173.

técnicas, alterações e conservação em Portugal, Espanha e Bélgica, Lisboa, Instituto Português de Conservação e Restauro, 2004; Los retablos. Técnicas, materiales y procedimientos, Madrid, Grupo Español IIC, 2006; La conservación de retablos. Catalogación, restauración y difusión, El Puerto de Santa María, Concejalía de Cultura, 2007; y Estructuras y sistemas constructivos en retablos: estudios y conservación, València, IVC+R, 2009. 
Charbonneau-Lassay, Louis, El bestiario de Cristo. El simbolismo animal en la Antigüedad y la Edad Media, II, Palma de Mallorca, Olañeta, 1997, págs. 559-564.

Chaumartin, Henri, "L'image de Saint-Antoine le Grand. Essai de critique iconographique", Bulletin de la Société Française d'Histoire de la Médecine, 26 (1932), págs. 333-385 y 413-441, y 27 (1933), págs. 6-14.

Couselo Bouzas, José, Galicia artística en el siglo XVIII y primer tercio del XIX, Santiago, Instituto Teológico Compostelano, 2005 ( $1^{\text {a }}$ ed.: 1933).

Cristóbal Antón, Luis, "Conservación y restauración de escultura y retablos en madera policromada", en Actas de los XI Cursos Monográficos sobre el Patrimonio Histórico, Santander-Reinosa, Universidad de Cantabria-Ayuntamiento de Reinosa, 2001, págs. 167-186.

Cruz Villalón, María, "La iconografía de Santa Eulalia en la Antigüedad y la Edad Media", en Eulalia de Mérida y su figura histórica. Actas del congreso del XVII centenario del martirio de Eulalia, Sevilla, Fundación El Monte, 2006, págs. 241-264.

Díaz Vaquero, María Dolores, La Virgen en la escultura cordobesa del Barroco, Córdoba, Caja de Ahorros de Córdoba, 1987.

Dietterlin, Wendel, Architectura von außtheilung, symmetria und proportion der fünff seulen, und aller darau $\beta$ volgender kunst arbeit, von fenstern, caminen und epitaphien..., Nürnberg, Hubrecht und Balthasar Carmor, 1598.

Echeverría Goñi, Pedro Luis, Policromía renacentista y barroca, Madrid, Historia 16, 1992.

Estructuras y sistemas constructivos en retablos: estudios y conservación, València, Universitat Politècnica, 2009.

Fernández González, Alberto, Fernando de Casas y Novoa, arquitecto del Barroco dieciochesco, Madrid, Fundación Universitaria Española, 2006.

Fernández Peña, María Rosa, "San Antonio abad, un santo antiguo pero muy actual”, en Campos y Fernández de Sevilla, Francisco Javier (coord.), El culto a los santos: cofradías, devoción, fiestas y arte, El Escorial, RCU Escorial-María Cristina, 2008, págs. 677-690.

Flórez, Enrique, España sagrada, XIII, Madrid, Antonio Marín, 1756, págs. 266-302.

Folgar de la Calle, María del Carmen, "Leis, Manuel de", Gran Enciclopedia Gallega, XIX, Santiago de Compostela-Gijón, Silverio Cañada, 1974, pág. 20.

Folgar de la Calle, María del Carmen, Simón Rodríguez, A Coruna, Fundación Barrié, 1989.

Folgar de la Calle, María del Carmen, "Retablo mayor de San Martín Pinario", en Galicia no tempo, Santiago de Compostela, Xunta de Galicia, 1990, págs. 302-311.

Folgar de la Calle, María del Carmen, "El retablo barroco gallego", Galicia no Tempo, Santiago de Compostela, Xunta de Galicia, 1991, págs. 201-220.

Folgar de la Calle, María del Carmen y Fernández Castiñeiras, Enrique, "Estilos en conflicto. El encuentro de un lenguaje académico y un gusto barroco en Santa María del Camino", en Fernández Castiñeiras, E. y Monterroso Montero, Juan Manuel (coords.), Santiago, ciudad de encuentros y presencias, Santiago de Compostela, Consorcio de Santiago-Alvarellos, 2012, págs. 227-232.

Folgar de la Calle, María del Carmen y López Vázquez, José Manuel, "Los retablos", en Santiago. San Martín Pinario, Santiago de Compostela, Xunta de Galicia, 1999, págs. 251-262. 
García Arranz, José Julio, Ornitología emblemática. Las aves en la literatura simbólica ilustrada en Europa durante los siglos XVI y XVII, Cáceres, Universidad de Extremadura, 1996.

García Iglesias, José Manuel, "Los retablos barrocos de la iglesia parroquial de Santa Baia de Vedra", en Jubilatio. Homenaje de la Facultad de Geografía e Historia a los profesores Don Manuel Lucas Álvarez y Don Ángel Rodríguez González, II, Santiago de Compostela, Universidade, 1987, págs. 631-640.

García Iglesias, J. M., "Evocaciones artísticas de Roma en Compostela. El culto a Pedro y Pablo", en Fernández Castiñeiras, E y Monterroso Montero, J. M. (coords.), Santiago, ciudad de encuentros..., págs. 45-71.

García Rodríguez, Carmen, El culto de los santos en la España romana y visigoda, Madrid, Instituto Enrique Flórez, 1966, págs. 284-303.

Gómez Moreno, María Elena, La policromía en la escultura española, Madrid, Escuela de Artes y Oficios Artísticos, 1943.

González-Alonso Martínez, Enriqueta, Tratado del dorado, plateado y su policromía. Tecnología, conservación y restauración, València, Universitat Politècnica, 1997.

Hevia Ballina, Agustín, "Santa Eulalia emeritense: su iconografía en la catedral de Oviedo", en Lamalfa Díaz, José Miguel (ed. y coord.), Santa Eulalia. Mito y realidad. Figuración y hermenéutica del texto, Oviedo, Universidad, 2010, págs. 113-168.

Kirschbaum, Engelbert (ed.), Lexikon der christlichen ikonographie, V y VIII, Freiburg, Herder, 1973 y 1976.

Künstle, Karl, Ikonographie der christlichen kunst, II, Freiburg, Herder, 1928.

La conservación de retablos. Catalogación, restauración y difusión, El Puerto de Santa María, Concejalía de Cultura, 2007.

López-Guadalupe Muñoz, Juan Jesús, "Retórica y color. Sobre la policromía en los retablos barrocos", en Barroco iberoamericano. Territorio, arte, espacio y sociedad, Sevilla, Ediciones Giralda, 2001, págs. 713-729.

López-Guadalupe Muñoz, Juan Jesús, "Mito e iconografía de la Virgen del Rosario en la Granada moderna", Cuadernos de Arte de la Universidad de Granada, 37 (2006), págs. 161-178.

López-Guadalupe Muñoz, Juan Jesús, "Iconografía de la Virgen del Rosario en el arte granadino", Communio, 39, 1 (2006), págs. 123-160.

López Vázquez, José Manuel, "Inventario e catalogación do patrimonio moble: metodoloxía e problemática", en Os profesionais da historia ante o patrimonio cultural. Liñas metodolóxicas, Santiago de Compostela, Xunta de Galicia, 1996, págs. 63-65.

López Vázquez, José Manuel, “Tipologías de la Virgen del Rosario en el arte gallego”, en $V$ Semana Mariana en Compostela, Santiago de Compostela, Real e Ilustre Cofradía Numeraria del Rosario, 2000, págs. 111-142.

López Vázquez, José Manuel, "Mentalidad barroca y plástica monástica: el conjunto retablístico de San Martín Pinario como síntesis de la ideología postridentina", en Sabik, Kazimier y Kunicka, Elzbieta (eds.), La cultura del Barroco español e iberoamericano y su contexto europeo, Warszawa, Uniwersytet Warszawski, 2010, págs. 427-436.

Los retablos. Técnicas, materiales y procedimientos, Madrid, Grupo Español IIC, 2006. 
Malaxecheverría, Ignacio, Bestiario medieval, Madrid, Siruela, 1989.

Mâle, Émile, Les saints compagnons du Christ, Paris, Editions Beauchesne, 1958.

Mâle, Émile, El arte religioso de la Contrarreforma. Estudios sobre la iconografía del final del siglo XVI y de los siglos XVII y XVIII, Madrid, Ediciones Encuentro, 2001.

Martín González, Juan José, "La policromía en la escultura castellana", Archivo Español de Arte, 26, 103 (1953), págs. 295-312.

Martín González, Juan José, “Avance de una tipología del retablo barroco", Imafronte, 3-5 (1987-1989), págs. 111-155.

Martín González, Juan José, El retablo barroco en España, Madrid, Editorial Alpuerto, 1993.

Martín González, Juan José, "Sagrario y manifestador en el retablo barroco español”, Imafronte, 12 (1998), págs. 25-50.

Meiffret, Laurence, Saint Antoine ermite en Italie (1340-1540). Programmes picturaux et dévotion, Rome, École Française, 2004.

Obras completas de Aurelio Prudencio, Madrid, BAC, 1981.

Ortega Romero, María del Socorro, "A propósito del ornato de la capilla del Pilar de la catedral de Santiago: el viaje de Fernando de Casas a Portugal", Actas do I Congresso Internacional do Barroco, II, Porto, Universidade do Porto, 1991, págs. 167-194.

Otero Túñez, Ramón, "Los retablos de la iglesia de la Compañía de Santiago", Cuadernos de Estudios Gallegos, 36, 8 (1953), págs. 406-408.

Otero Túñez, Ramón, "El retablo mayor de San Martín Pinario", Cuadernos de Estudios Gallegos, XXXIV, 11 (1956), págs. 229-243.

Otero Túñez, Ramón, "Los retablos del crucero de San Martín Pinario", Boletín de la Universidad Compostelana, 64 (1956), págs. 277-286.

Otero Túñez, Ramón, "Miguel de Romay, retablista”, Compostellanum, III, 2 (1958), págs. 205-207.

Otero Túñez, Ramón, El legado artístico de la Compañía de Jesús a la Universidad de Santiago, Santiago de Compostela, Universidade, 1986, págs. 60-63.

Pena Buján, Carlos, "Gaude Virgo Gloriosa. Reflexiones sobre la capilla de la Virgen de los Ojos Grandes de la Catedral de Lugo", Abrente, 32-34 (2000-2002), págs. 167-190.

Pena Buján, Carlos, “¿Decoro, decoración o mera evocación? El sentido de los órdenes arquitectónicos gallegos del Renacimiento y el Barroco”, Sémata, 14 (2003), págs. 413-414.

Pérez Larrán, Carmen, "El retablo de la Expectación de la catedral de Tui: la introducción del estípite en Galicia", Actas del IX congreso de novos historiadores de Galicia, Santiago de Compostela, Asociación Galega de Historiadores, 2002, págs. 35-39.

Pita Galán, Paula, "Extravagancias y fantasías. Estudio de las fuentes ornamentales del Barroco gallego", en Barral Ribadulla, María Dolores et al. (coords.), Mirando a Clío. El arte español espejo de su historia. Actas del XVIII congreso español de historia del arte, Santiago de Compostela, Universidade, 2012, págs. 2049-2061.

Policromia. A escultura policromada religiosa dos séculos XVII e XVIII. Estudo comparativo das técnicas, alterações e conservação em Portugal, Espanha e Bélgica, Lisboa, Instituto Português de Conservação e Restauro, 2004.

Réau, Louis, Iconografía del arte cristiano, Barcelona, Ediciones del Serbal, 1996-2000. 
Recio Veganzones, Alejandro, "La mártir Santa Eulalia de Mérida en calendarios y martirologios, en la devoción popular y en su iconografía (siglos IV-VII)", Extremadura Arqueológica, 3 (1992), págs. 81-110.

Recio Veganzones, Alejandro, "La mártir Eulalia en la devoción popular: Prudencio primer promotor de su culto, peregrinaciones, expansión de sus reliquias e iconografía (siglos IV-VII)", en IV Reunió d'Arqueologia Cristiana Hispànica, Barcelona, Institut d'Estudis Catalans, 1995, págs. 317-336.

Rega Castro, Iván, "De la columna panzuda al estípite: el retablo del Barroco en el noroeste de la Península Ibérica y las consecuencias de la Reforma católica”, en Atas do IV Congresso Internacional do Barroco Ibero-Americano, Ouro Preto, C/Arte, 2006, págs. 138-140.

Rega Castro, Iván, "Barroco de estípites en Santo Estevo de Ribas de Sil, o la incógnita acerca de los obradores benedictinos del siglo XVIII", en Monterroso Montero, J. M. y Fernández Castiñeiras, E. (eds.), Entre el agua y el cielo. El patrimonio monástico de la Ribeira Sacra, Santiago de Compostela, Universidade, 2012, págs. 191-213.

Riesgo Chueca, Pilar, Pasionario hispánico, Sevilla, Universidad de Sevilla, 1995, págs. 5169.

Ríos Miramontes, María Teresa, "Estudio arquitectónico de la capilla del Pilar de la catedral de Santiago de Compostela", Archivo Español de Arte, 61, 244 (1988), págs. 350-353.

Rodríguez Gutiérrez de Ceballos, Alfonso, "Motivos ornamentales en la arquitectura de la Península Ibérica entre Manierismo y Barroco", en España entre el Mediterráneo y el Atlántico. Actas del XXIII congreso internacional de historia del arte, II, Granada, Universidad, 1977, págs. 553-559.

Rodríguez Gutiérrez de Ceballos, Alfonso, El retablo barroco, Madrid, Historia 16, 1992.

Sánchez López, Juan Antonio, "Iconografía e iconología del pelícano: un ensayo sobre la reconversión del concepto de filantropía", Boletín de Arte, 12 (1991), págs. 127-146.

Sánchez-Mesa Martín, Domingo, Técnica de la escultura policromada granadina, Granada, Universidad, 1971.

Sebastián López, Santiago, Contarreforma y Barroco. Lecturas iconográficas e iconológicas, Madrid, Alianza Editorial, 1985 (1ª ed.: 1981).

Sebastián López, Santiago, El Fisiólogo atribuido a San Epifanio, seguido de El bestiario toscano, Madrid, Tuero, 1986.

Taín Guzmán, Miguel, "Los mármoles portugueses de la capilla del Pilar de la catedral de Santiago", en Fernández Cortizo, Camilo, González Lopo, Domingo y Martínez Rodríguez, Enrique (eds.), Universitas. Homenaje a Antonio Eiras Roel, II, Santiago de Compostela, Universidade, 2002, págs. 75-76.

Tejada Vizuete, Francisco, "Eulalia de Mérida en la literatura y en el arte. De los orígenes al siglo XVIII", en Barrera Antón, José Luis de la y Álvarez Martínez, José María (dirs.), Eulalia de Mérida y su proyección en la historia, Madrid, Ministerio de Cultura, 2004, págs. 111-137.

The fantastic engravings of Wendel Dietterlin, New York, Dover Publications Inc., 1968. Introducción de Adolf K. PlaczeK.

Trens Ribas, Manuel, María. Iconografía de la Virgen en el arte español, Madrid, Plus Ultra, 1947. 
Utro, Umberto, "Alle origini dell'iconografia paolina", en Bucarelli, Ottavio y María Morales, Martín (dirs.), Paulo apostolo martyri. L'apostolo San Paolo nella storia, nell'arte e nell'archeologia, Roma, Gregorian \& Biblical Press, 2011, págs. 27-44.

Vigo Trasancos, Alfredo, La fachada del Obradoiro de la catedral de Santiago (1738-1750). Arquitectura, triunfo y apoteosis, Santiago de Compostela, Consorcio de Santiago-Electa, 1996.

Vila Jato, María Dolores, Lugo barroco, Lugo, Diputación de Lugo, 1989.

Villaverde Solar, María Dolores, Patrimonio artístico del arciprestazgo de Ribadulla, vol. III, A Coruña, Edinosa, 2000.

Villaverde Solar, María Dolores, "La evolución del retablo barroco en Galicia", en Barroco iberoamericano. Territorio, arte, espacio y sociedad, Sevilla, Ediciones Giralda, 2001, págs. 763-781.

Villaverde Solar, María Dolores, "La eucaristía en el arte gallego: los sagrarios-expositores", en Campos y Fernández de Sevilla, F. J. (coord.), Religiosidad y ceremonias en torno a la eucarístia. Actas del simposium, II, El Escorial, RCU Escorial-María Cristina, 2003, págs. 1.165-1.186.

Vredeman de Vries, Hans, Das erst buch, gemacht auff de zwey colommen dorica und ionica..., Antwerp, Hieronymus Cock, 1565.

Vredeman de Vries, Hans, Architectura, oder, bauung der antiquen auss dem Vitruuius..., Antwerpie, Geerhardt de Jode, 1581. 